, 


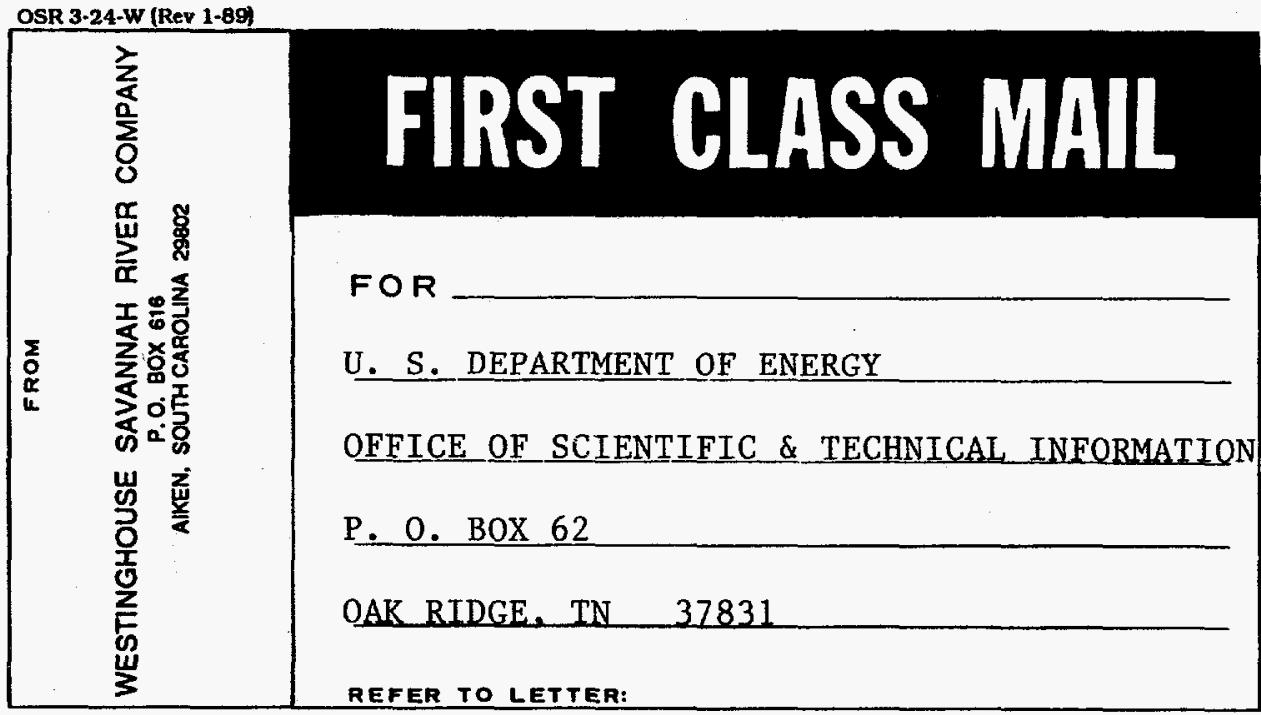




\section{DISCLAIMER}

Portions of this document may be illegible electronic image products. Images are produced from the best available original document. 
WSRC-TR-940408

Rev 0

August 1994

Results of the Quarterly Tritium Survey of Fourmile Branch and its Seeplines in the F-and $\mathrm{H}$-Areas of SRS:

March 1994(U)

V. A. Rogers, K. L. Dixon, and B. B. Looney

Prepared for the U.S. Department of Energy under contract no. DE-AC09-89SR18035 


\title{
Results of the Quarterly Tritium Survey of Fourmile Branch and its Seeplines in the F and H Areas of SRS: March 1994
}

\author{
V. A Rogers, K. L. Dixon, and B. B. Looney
}

\begin{abstract}
The Environmental Sciences Section (ESS) of the Savannah River Technology Center (SRTC) established a quarterly monitoring program of the Fourmile Branch (FMB) stream and its associated seepline down gradient from the F- and H-Area seepage basins. The program surveys and tracks changes in tritium, specific conductivity, and pH primarily for seepline water; however, a few stream locations have been added. Measurements from the eighth quarterly survey (March 1994) showed similar to slightly lower tritium and conductivity measurements and similar $\mathrm{pH}$ values compared to previous studies. Decreased tritium concentrations and conductivity values, as compared to the previous survey, are attributed to the seasonal rise in the water table since the December 1993 sampling event. However, overall results of the tritium survey and stream monitoring data (Looney et al., 1993) suggest that the tritium plume resulting from the operation of the seepage basins is flushing from the FMB system.
\end{abstract}

\section{Executive Summary}

In March 1994 ESS surveyed the FMB seepline down gradient from the F- and H-Area seepage basins for tritium, specific conductivity, and $\mathrm{pH}$. The survey was the eighth of ten quarterly surveys scheduled to monitor the movement of contaminants from the basins since closure in 1990. Surface-water samples were collected from 60 locations along the seepline and from three stream locations along FMB. The seepline locations include 22 from $F$ Area, 22 from $H$ Area, and 16 from the seepline south of 643-E, which is al decommissioned area in the Solid Waste Disposal Facility. The Savannah River Laboratory (now SRTC) sampled 44 of these locations in 1989 as part of an extensive characterization study (Haselow et al. 1990). ESS found that tritium activities in F- and $\mathrm{H}$ Area seeplines in March 1994 were significantly lower than the activities measured by Haselow et al. (1990). However, tritium increased at four sample locations that are the most distant sample points from the capped basins.

Theoretically, lower water discharge shifts the plume upward and the arrival point away from FMB and toward the seepage basins. Therefore, the more concentrated portion of the plume moved within the sampling zone at the seepline intercept. This should increase tritium concentrations at the scepline intercepts at both seeplines.
Previous sampling events consistently show a declining trend in tritium activity at the $\mathrm{F}$ and $\mathrm{H}$ Area seepline. Total tritium fluxes to the wetlands and FMB have steadily declined since basin closure (Looney et al., 1993) and overall results from the tritium survey support this finding. Differences in tritium activities measured at individual seepline sampling locations from one sampling event to the next represent seasonal variability in depth to water table, variable amounts of rainfall, as well as changes due to the flushing of the plume from the wetland system. Conclusions about tritium fluxes to the wetlands and FMB should consider the long-term surface water, seepline, and groundwater monitoring data and not rely on quarterly changes in concentrations at seepline monitoring stations alone.

March 1994 conductivity measurements exhibited the same general trends as tritium activities in $\mathrm{F}$ and $\mathrm{H}$ Areas. Concentrations of hydrogen ions increased in both areas, indicating that conditions are changing from extremely acid $(\mathrm{pH}<4.5)$ and strongly to slightly acid ( $\mathrm{pH} 5.1$ 6.5 ), which is closer to normal for this type of wetland. Aluminum concentrations measured along the seepline in 1989 (Haselow et al, 1990) were high enough to be potentially toxic to plants. Each increase in $\mathrm{pH}$ reduces the solubility 
of aluminum, thereby decreasing the potential for aluminum toxicity to plants. Concentrations of aluminum; as well as other metals, measured along the seepline in July 1992 were substantially lower than 1989 concentrations reflecting the increase in pH (Dixon and Rogers, 1993e). Field observations revealed that vegetation in all areas, except the wetland below location FSP014, is showing noticeable recovery.

The seepline south of 643-E, along a tributary of FMB, is influenced by tritium migrating from the burial grounds. The tributary (old F-Area effluent ditch) is a natural drainage that received effluent discharge from F-Area Separations prior to construction of the engineered effluent canal. March 1994 tritium activities ranged from 19 to $748 \mathrm{pCi} / \mathrm{mL}$ on the east side of the drainage and from 95 to $24,500 \mathrm{pCi} / \mathrm{mL}$ on the west side. The tritium activity measured in the stream of the natural drainage was $16,100 \mathrm{pCi} / \mathrm{mL}$. Results suggest that the tritium outcrop area has been delineated by the sampling locations established on the west side of the drainage channel. Conductivity and $\mathrm{pH}$ measurements taken on both sides of the drainage were similar to those recorded in December 1995 and were within the range of normal values for this type wetland. The low conductivity values measured along the drainage-way suggest that the tritium plume outcropping in the area emanates from $643-E$ because wastes introduced into 643-E contained low levels of salt ions compared to the waste in the F- and $\mathrm{H}$-Area basins.

\section{Introduction}

Seepange basins in the $\mathrm{F}$ and $\mathrm{H}$ Areas of SRS received low-level radioactive waste effluent from the chemical separation processes in the general separation areas. The basins retained the effluent and slowly released it into the soil. The waste effluent consisted principally of sodium hydroxide, nitric acid, low levels of various radionuclides, and some metals (Killian et al., 1985a and 1985b). Discharges of tritiated water to the seepage basins accounted for most of the radioactivity (Fenimore and Horton, 1972).

The Savannah River Laboratory conducted an extensive study designed to characterize the shallow groundwater outcropping into FMB and its associated seepline in 1988 and 1989 (Hasclow et al., 1990). As a part of this study, Haselow et al. (1990) surveyed for tritium, $\mathrm{pH}$, and conductivity. Researchers found low $\mathrm{pH}$ and elevated conductivity and tritium values along the seeplines and concluded that contaminants leaching from the F- and $\mathrm{H}$-Area seepage basins were impacting the wetlands below the basins. SRS stopped discharges to the seepage basins in 1988 and capped and sealed the basins in 1990 to eliminate the source of contaminants. Scientists hypothesized that after the elimination of the contaminant source, annual rainfall and natural groundwater flow would flush the remaining contaminant plume out of the shallow groundwater over time. After the contaminant plume in the shallow groundwater is flushed out, the impacted wetland systems immediately down gradient from the basins should recover.

To investigate this hypothesis, a quarterly sampling program was established in May 1992. ESS sampled 44 of the seepline locations sampled by Haselow et al., (1990) for tritium, $\mathrm{pH}$, and specific conductivity. The Haselow et al. (1990) results established the baseline to which the results from the quarterly sampling program are compared. These collection points were chosen as the baseline because they are the only data available that were collected before the basin discharges were discontinued: The Haselow ef al. (1990) data should be representative of conditions immediately prior to closing the basins. This sampling program is intended to complement semiannual sampling of the seepline for selected Resource Conservation Recovery Act, Appendix IX, characterization, which began in July 1992. A report summarizing results from the semiannual sampling program is completed (Dixon and Rogers, 1993e).

The Environmental Protection Department expressed concern about possible seepage of tritium and other contaminants from an area in the southwest corner of 643-E. To investigate this possibility, numerous sampling locations on the H-Area seepline south of $643-\mathrm{E}$ were established and have been incorporated into the quarterly sampling plan.

\section{Methods}

ESS conducted the eighth sampling for the quarterly tritium survey in March 1994. Sampling locations were the same as those selected in the seventh round of sampling. This sclection, according to 1989 data, exhibited high and low values for the three variables of concern. Attempts were made to establish even ground 
coverage along both seeplines. ESS collected 60 samples from the seeplines in $F$ and $H$ Area: 22 from the F-Area seepline, 22 from the H-Area scepline, and 16 from the FHB seepline south of 643-E Area. ESS also collected three stream samples from locations on FMB. Figures 1 and 2 show the sampling locations.

Prior to sampling for the first quarter in May 1992, the Health Protection Department (HPD) collected soil samples from several locations along both seeplines and monitored them for gamma radioactivity. HPD did not detect gamma radiation; therefore, ESS selected rubber boots and disposable rubber gloves as protective clothing to prevent dermal contact with seepline water during sampling operations.

Seepline sampling locations had been previously marked and labeled with P.VC stakes. Samples were collected within a three foot radius of the PVC stake by boring a hole into the soil with a small bucket soil auger, generally six inches and not more than eighteen inches deep to obtain sample. To collect water for tritium analysis, polyethylene sample containers $(25 \mathrm{~mL})$ were dipped into the water until full and then capped. The outside of each container was then rinsed with deionized water and sealed in a small polyethylene bag to minimize the possibility of contamination. The small bags were then sealed in a large polyethylene bag. The Environmental Monitoring Section (EMS) performed tritium analysis (total activity). EMS counted $5 \mathrm{~mL}$ aliquots for 20 minutes, which yielded a lower detection limit of $1.3 \mathrm{pCi} / \mathrm{mL}$ (WSRC, 1992).

ESS measured specific conductivity and $\mathrm{pH}$ in situ with conductivity and $\mathrm{pH}$ electrodes (WSRC-L]4.1, 1992a and 1992b). The electrodes were rinsed with deionized water after each sampling. All sampling equipment was thoroughly rinsed with deionized water at the end of each day.

\section{Results and Observations}

Concentrations of variables measured at seepline sampling locations fluctuate throughout the year. Climatic and seasonal conditions, especially rainfall amounts, influence measured concentrations. Seepline measurements are made on water collected from fixed locations at the distal end, or toe slope outcrop, of the contaminant plume. Because the plume is dynamic (i.e., influenced by weather and other activities in the area) seepline monitoring is sensitive to long-term changes and seasonal/transient influences. Groundwater flow paths in $F$ and $H$ Area are complex, as illustrated in Figures 3 and 4. Recharge to the groundwater is primarily due to infiltration of rainwater (rainfall minus runoff and evapotranspiration). Groundwater then moves laterally to FMB and its tributaries.

As the water travels toward the stream, additional infiltration forces up-gradient water deeper. Near the stream, the flow lines rise to the surface, emerging between the seepline and the stream (which acts as the groundwater "drain"). This classic vertical trajectory, a path curving downward near the groundwater divide and then upward into draining surface water, is shown as flow lines on Figures 3 and 4.

Figure 3 shows the flow lines without contaminated water from the seepage basins and Figure 4 shows the addition of contaminated flow lines resulting from operations of the basins. The theoretical plume geometry. is clearly confirmed by the real vertical profile of the F-Area Seepage Basin plume based on the detailed grid wells available in the 1970 s (Looney et al., 1993). Changes in the water balance in the area influence the flow velocity, tend to move the plume either deeper or shallower, and cause the location of the contaminated water to move. This is especially important to data interpretation if the "toe" of the plume is shifting relative to the fixed sample locations. Figure 5 summarizes the projected changes in the plume based on a range of transient activities. Increased rainfall (or other activities that increase infiltration, such as harvesting trees) result in increased plume velocity and movement downward and away from the seepline. This decreases contaminant concentrations at the seepline sampling locations. Less infiltration decreases plume velocity and the plume moves upward and closer to the seepline. This results in increased contaminant concentrations as measured at the seepline sampling locations.

Low rainfall for a few months prior to sampling increases constituent concentrations; and high rainfall decreases constituent concentrations in the shallow groundwater at the seepline intercept. Rainfall measured at SRS at the weather station in F Area in January and February 1994 was $21.1 \mathrm{~cm}$. From 1960 to 1991 , the average rainfall measured in $F$ Area for the months of January and February was $22.6 \mathrm{~cm}$. 
This indicates that average rainfall in the area was slightly below normal for this sample period; however, because of reduced evapotranspiration in the winter months the water table normally reaches its high for the year about mid-March. Rainfall from April 1993 through February 1994 was $22.7 \mathrm{~cm}$ below the long-term average.

Figure 6 shows a comparison of 1994 rainfall to the long-term average (1960-1991) for January and February 1994. It is hypnotized that below average rainfall observed in the area for this period would cause contaminant concentrations to decrease at sample locations closer to the basins and to increase at the more distant locations. This increase in infiltration causes the toe of the plume to migrate downward through the soil profile and the arrival point to move away from the basins and towards FMB. In general this pattern was observed in the March 1994 sampling event. Four sample locations were above the March 1989 readings with three of the samples showing tritium activity of less than $1300 \mathrm{pCi} / \mathrm{mL}$; all four locations were the more distant from basins.

Figures 7 through 12 show comparisons of March 1989 with December 1993 and March 1994 tritium, conductivity, and $\mathrm{pH}$ measurements for locations in $\mathrm{F}$ - and $\mathrm{H}$-Area seeplines. Data for the first seven surveys can be found in Dixon and Rogers (1992, 1993a, 1993b, 1993c, 1993d, 1993e, and 1994), and Rogers et al., (1994). Figures 13 through 15 show the data for the FMB stream locations. Figures 16 through 18 show the data for the sampling locations along the seepline and one stream sample south of $643-\mathrm{E}$ in $\mathrm{H}$ Area. These sampling locations were identified with the prefix FHB.

\section{F- and H-Area Seepline Tritium Measurements}

\section{F Area}

March 1994 tritium values in the F-Area seepline ranged from 11 to $7,730 \mathrm{pCi} / \mathrm{mL}$ (see Figure 6 and Table 2). In F Area, water was attained within approximately 18 inches of the soil surface. Two 22 sampling locations had abovebackground tritium activities that exceeded the 1989 measurements by more than $10 \%$. The tritium activity of $7,730 \mathrm{pCi} / \mathrm{mL}$ measured at FSP035 is less than the $11,000 \mathrm{pCi} / \mathrm{mL}$ recorded at this ocation in March 1989. In 1989, maximum tritium activity $(14,000 \mathrm{pCi} / \mathrm{mL})$ was measured at FSP014 and FSP034 sample locations.

As with data from previous quarters, a Wilcoxon signed-rank test was conducted to compare March 1994 tritium activities to March 1989 activities. The Wilcoxon signed-rank test uses the sign and the magnitude of the rank of the differences between pairs of measurements to compare nonparametric data (Daniel, 1978). This test was chosen because it allows comparisons of paired data without assumptions of normality. The results showed that the March 1994 concentrations were significantly less. $(P=0.0009)$ than the 1989 concentrations.

\section{H Área}

Tritium values in the $\mathrm{H}$-Area seepline ranged from 42 to $8,650 \mathrm{pCi} / \mathrm{mL}$ (Figure 8 and Table 3 ). Of the 22 sampling locations, two had abovebackground tritium activities that exceeded the 1989 measurements by more than $10 \%$, however; these locations showed a decrease from the December 1993 data. No tritium activity exceeded the maximum value of $24,000 \mathrm{pCi} / \mathrm{mL}$ measured in 1989 and both locations showing increase had relatively low activity ( values of 930 and $1270 \mathrm{pC} / \mathrm{mL}$ ) and were influenced by floodplain rather than only seepage from the uplands, therefore inducing greater variability.

As with data from F Area, a Wilcoxon signedrank test was conducted to compare March 1994 tritium activities to March 1989 activities. The results showed that the March 1994 concentrations were significantly less $(P=0.0001)$ than the 1989 concentrations for H Area. No sample location showed an increase in tritium activity compared to March 1989 sample events.

Figures 7 and 8 show that tritium activity at $F$ and $H$ Area for the March 1994 sampling event decreased at 39 sample locations while five locations increased compared to the December 1993 sampling event. These results were predicted for this time of year when the water table occurs closer to the soil surface. Previous sampling events consistently showed a declining trend in tritium concentrations at the F-and $\mathrm{H}$ Area seeplines. For the period prior to March 1994, the below average rainfall caused the plume to move upward through the soil profile while the toe of the plume moved back towards the secpage basins and the seepline intercept. 
When the rainfall returns to normal, the plume should move deeper into the soil profile and again outcrop closer to FMB. This trend is noted in the March 1993 data. It is important to note that total tritium fluxes to the wetlands and FMB have steadily declined since basin closure (Looney et al., 1993) and that overall results of the tritium survey support this finding. Differences in tritium concentrations measured at seepline sampling locations from one sampling event to the next represent seasonal variability and variable rainfall as well as changes due to the flushing of the plume from the wetland system. Conclusions about tritium fluxes to the wetlands and FMB should consider the complexity of the groundwater.system and should be based on long-term surface water, seepline, and groundwater monitoring data and not on quarterly changes in concentrations at seepline monitoring stations.

\section{F- and $\mathrm{H}$-Area Seepline Conductivity Measurements}

\section{F Area}

Conductivity measurements in the F-Area seepline ranged from 27 to $2264 \mu \mathrm{S} / \mathrm{cm}$ (see Figure 9 and Table 2). Due to the variability of conductivity measurements, differences of 100 $\mu \mathrm{S} / \mathrm{cm}$ or more are considered significant. Of the 22 locations sampled at the F-Area seepline, one location measured more than $100 \mu \mathrm{S} / \mathrm{cm}$ above the 1989 measurements. A comparison of the graphs in Figures 7 and 9 suggest that conductivity follow the same general trends as the tritium activities. Using a Spearman rank correlation test for nonparametric data, it was found that the probability that tritium and conductivity exhibited independent trends $(\mathrm{P}<0.001)$. The rank correlation coefficient was found to be rs=0.91, suggesting that the two parameters exhibit the same trends. This similarity is to be expected because tritium serves to track the movement of the contaminant plume from the basins (Haselow et al., 1990).

\section{H Area}

Conductivity measurements in the H-Area seepline ranged from 35 to $344 \mu S / \mathrm{cm}$. (see Figure 10 and Table 3 ). Nonc of the 22 sampling locations, had a measurement of more than $100 \mu \mathrm{S} / \mathrm{cm}$ above the 1989 measurements. Data in Figures 8 and 10 suggest that conductivity and tritium are following the same general trends. The Spearman rank correlation test for nonparametric data was used to investigate the correlation of $\mathrm{H}$-Area tritium activities and conductivity values. The probability that the two parameters exhibited independent trends was $\mathrm{P}<0.001$. The rank correlation coefficient $(r s=0.80)$ for $H$ Area was lower than that for F Area, but still suggested a good correlation.

\section{F- and $\mathrm{H}$-Area Seepline $\mathrm{pH}$ Measurements}

F Area pH values ranged from 3.9 to 6.4 with an average value of 5.0 (see Figuire 11 and Table 2). H-Area $\mathrm{pH}$ values ranged from 4.5 to 6.5 with an average of 5.6 (see Figure 12 and Table 3 ). The $\mathrm{pH}$ for the entire seepline (F and $\mathrm{H}$ Areas combined) averaged 5.3. The average increased 0.4 units over the 4.9 average in 1989 (Haselow et al., 1990). The hydrogen ion concentration has decreased by about threefold compared to 1989 measurements. The increase in $\mathrm{pH}$ will affect the solubility of metals in the soil, which should improve the soil water chemistry and enhance the recovery of wetland vegetation stressed indirectly by low $\mathrm{pH}$. Aluminum concentrations measured along the seepline in 1989 (Haselow et al., 1990) were high enough to be toxic to plants. Increases in $\mathrm{pH}$ from an average of 4.9 in 1989 to 5.3 reduced the amount of aluminum in solution, thereby reducing it as a possible source of plant toxicity. Concentrations of aluminum and other metals measured along the seepline in July 1992 were substantially lower than 1989 concentrations, reflecting the increase in $\mathrm{pH}$ (Dixon and Rogers, 1993e). Field observations revealed that vegetation in all of the stressed areas except the wetland south of sample location FSP014 is making noticeable recovery.

\section{Fourmile Branch Measurements}

Figures 13 through 15 show the tritium, conductivity and $\mathrm{pH}$ values for the FMB stream sampling locations (Table 4 provides the data used in the figures). Tritium activities at these locations ranged from 34 to $375 \mathrm{pCi} / \mathrm{mL}$. These values were consistent with previous data and show increases in tritium down stream as the seepline water enters the channel of FMB. Conductivity measurements ranged from 58 to $67 \mu \mathrm{S} / \mathrm{cm}$ and $\mathrm{pH}$ ranged from 6.2 to 6.4 . Both conductivity and $\mathrm{pH}$ values were close to normal values. 


\section{Solid Waste Disposal Facility (643-E) Seepline Measurements}

The graphs in Figures 16 through 18 show tritium, conductivity, and $\mathrm{pH}$ values for the seepline and stream sampling locations south of 643-E, which is part of the Solid Waste Disposal Facility. Table $S$ provides the data used in the figures. This seepline is along the natural drainage (old F-Area effluent ditch) that was used to discharge effluent from F-Area separations prior to the construction of the engineered effluent canal.

Tritium activities for the locations on the east side of the drainage ranged from 19 to $748 \mathrm{pCi} / \mathrm{mL}$. Activities on the west side of the drainage ranged from 95 to $24,500 \mathrm{pCi} / \mathrm{mL}$. The tritium activity at the stream location in the drainage (FHB012) was $16,100 \mathrm{pCi} / \mathrm{mL}$.

Conductivity measurements on both sides of the drainage were near background at most locations and ranged from 27 to $128 \mu \mathrm{S} / \mathrm{cm}$. Conductivity values are-typical of the conductivity values being reported in the water table wells in the vicinity of the old F-Area effluent ditch (EMS, 1993). Using the Spearman rank correlation test, no correlation ( $\mathrm{rs}=-\mathbf{0 . 1 7}$ ) was found between conductivity and tritium for these locations. Reaction values ranged from $\mathrm{pH} 4.4$ to $\mathrm{pH} 6.1$ with an average of $\mathrm{pH} 5.2$.

These results are consistent with the Haselow et al. (1990) results for the western portion of the H-Area seepline, particularly near location HSP103. Haselow et al. (1990) found that down gradient from $643-\mathrm{E}$, conductivity values were near background while tritium concentrations were elevated. This was attributed to tritiated wastes deposited in 643-E. Tritium activities measured along the seepline down gradient of 643-E (particularly sample points on the west side) suggest that tritium migrating from $643-E$ and outcropping in this area is substantial. The appearance of tritium on the west side as opposed to the east side of the drainage suggests that soil material placed in the northern. reaches of the natural drainage forced the tritium plume to outcrop down gradient. It appears that the groundwater and tritium are moving below the fill material and outcropping on the west side of the drainage channel. The results suggest that the sampling locations on the west side of the drainage have delineated the tritium plume with the center located at or near FHB018.

\section{Conclusion}

Tritium concentrations measured at most locations during March 1994 decreased or remained relatively unchanged compared to previous sampling events. These results vary only slightly from previous sampling events and are attributed to the dynamic nature of the tritium plume movement. Below-normal rainfall for the past nine months caused the toe of the tritium plume to migrate toward the seepline intercept and away from FMB. Total tritium fluxes to the wetlands and FMB have steadily declined since basin closure (Looney et al., 1993) and overall results from the tritium survey support this finding. These findings support the hypothesis that the tritium plume in $F$ and $H$ Area is being flushed from the shallow groundwater. Differences in tritium concentrations measured at seepline sampling locations from one sampling event to the next represent seasonal and rainfall variability as well as changes due to flushing of the contaminant plume from the wetland system. No correction has been made for tritium decay because of the short time between sample events. Conclusions about tritium fluxes to the wetlands and FMB should consider the complexity of the groundwater system and should be based on long-term surface water, seepline, and groundwater monitoring data and not on quarterly changes in concentrations at seepline monitoring locations.

Evaluation of data from 16 seepline locations south of the 643-E Area indicates that tritium migrating from $643-E$ is outcropping at the F-Area effluent drain, particularly on the west side of the stream channel. It appears that sampling locations on the west side of the channel have delineated the tritium outcrop area with the present climatic and hydrologic conditions.

\section{References}

Daniel, W. W. 1978. Applied Nonparametric Statistics. Houghton. Mifflin Company, Boston, MA.

Dixon, K. L. and V. A. Rogers. 1992. Results of the First Quarter Tritium Survey of the F. and H-Area Seeplines: May 1992. WSRCTR-92-304, Westinghouse Savannah River Company, Savannah River Technology Center, Aiken, SC. 
Dixon, K. L. and V. A. Rogers. 1993a. Results of the Second Quarter Tritium Survey of the Fand H-Area Seeplines: September 1992. WSRC-TR-93-129, Westinghouse Savannah River Company, Savannah River Technology Center, Aiken, SC.

Dixon, K. L. and V. A. Rogers. 1993b. Results of the Third Quarter Tritium Survey of the F. and H-Area Seeplines: December 1992. WSRC-TR-93-284, Westinghouse Savannah River Company, Savannah River Technology Center; Aiken, SC.

Dixon, K. L. and V. A. Rogers. 1993c. Results of the Fourth Quarter Tritium Survey of the Fand H-Arrea Seeplines: March/April 1993. WSRC-TR-93-526, Westinghouse Savannah River Company, Savannah River Technology Center, Aiken, SC.

Dixon, K. L and V. A. Rogers. 1993d. Results of the Quarterly Tritium Survey of Fourmile Branch and Its Seeplines in the $F$ - and $H$ Areas of SRS: June 1993. WSRC-TR-93656, Westinghouse Savannah River Company, Savannah River Technology Center, Aiken, SC.

Dixon, K. L. and V. A. Rogers. 1993e. SemiAnnual Sampling of Fourmile Branch and Its Seeplines in the F and H Areas of SRS: July 1992. WSRC-TR-93-289, Westinghouse Savannah River Company, Savannah River Technology Center, Aiken, SC.

Dixon, K. L. and V. A. Rogers, and B. B. Looney. 1994. Results of the Quarterly Tritium Survey of Fourmile Branch and its Seeplines in the $F$ and $H$ Areas of SRS: September $1993(U)$. WSRC-TR-94-0286ESS, Westinghouse Savannah River Company, Savannah River Technology Center, Aiken, SC.

Rogers, V. A., K. L. Dixon, and B. B. Looney. 1994. Results of the Quarterly Tritium Survey of Fourmile Branch and its Seeplines in the $F$ and $H$ Areas of SRS: December 1993 (U). WSRC-TR-94-0342, Westinghouse Savannah River Company, Savannah River Technology Center, Aiken, SC.

Environmental Monitoring Section. 1993. The Savannah River Site's Groundwater Monitoring Program, Second Quarter Report. ESH-EMS-930097, Westinghouse Savannah River Company, Aiken SC.
Fenimore, J. W. and J. H. Horton. 1972. Rating History and Environmental Effects of Seepage Basins in Chemical Separations Areas of the Savannah River Plant. DPST. 72-548, E. I. du Pont de Nemours and Company, Savannah River Laboratory, Aiken, SC.

Haselow, J. S., M. Harris, B. B. Looney, N. V. Halverson, and J. B. Gladden. 1990. Analysis of Soil and Water at the Fourmile Branch Seepline Near the $F$ and $H$ Area of SRS (U). WSRC-RP-90-0S91, WSRC-TR92-304, Westinghouse Savannah River Company, Savannah River Technology Center, Aiken, SC. Savannah River Laboratory, Aiken, SC.

Killian, T. H., N. L. Kolb, P. Corbo, and L. W. Marine. 1985a. F-Area Seepage Basins. DPST-85-704, E. I. du Pont de Nemours and Company, Savannah River Laboratory, Aiken, SC.

Killian, T. H.; N. L. Kolb, P. Corbo, and I. W. Marine. 1985b. H-Area Seepage Basins. DPST-85-706, E. I. du Pont de Nemours and Company, Savannah River Laboratory, Aiken, SC.

Looney, B. B., J. S. Haselow, C. M. Lewis, M. K. Harris, D. E. Wyatt, C. S. Hetrick. 1993. Projected Tritium Releases from $F$ \& $H$ Area Seepage Basins and the Solid. Waste Disposal Facilities to Fourmile Branch (U). WSRC-RP-93-459, Westinghouse Savannah River Company, Savannah River Technology Center, Aiken, SC. Savanoah River Laboratory, Aiken, SC.

WSRC 1992a. 1992. Determination of Tritium in Water. (WSRC-3Q1-4). Procedure 2760, Rev 0. Westinghouse Savannah River Company, Aiken, SC.

WSRC-L14.1. 1992b. Procedure for ColeParmer Portable Conductivity Meter Model 1481-40. Procedure 2-79, Rev 1. Westinghouse Savannah River Company, Aiken, SC.

WSRC-L14.1. 1992c. Procedure for ColeParmer Model 5985-80 pH Meter. Procedure 2-81, Rev 1. Westinghouse Savannah River Company, Aiken, SC. 


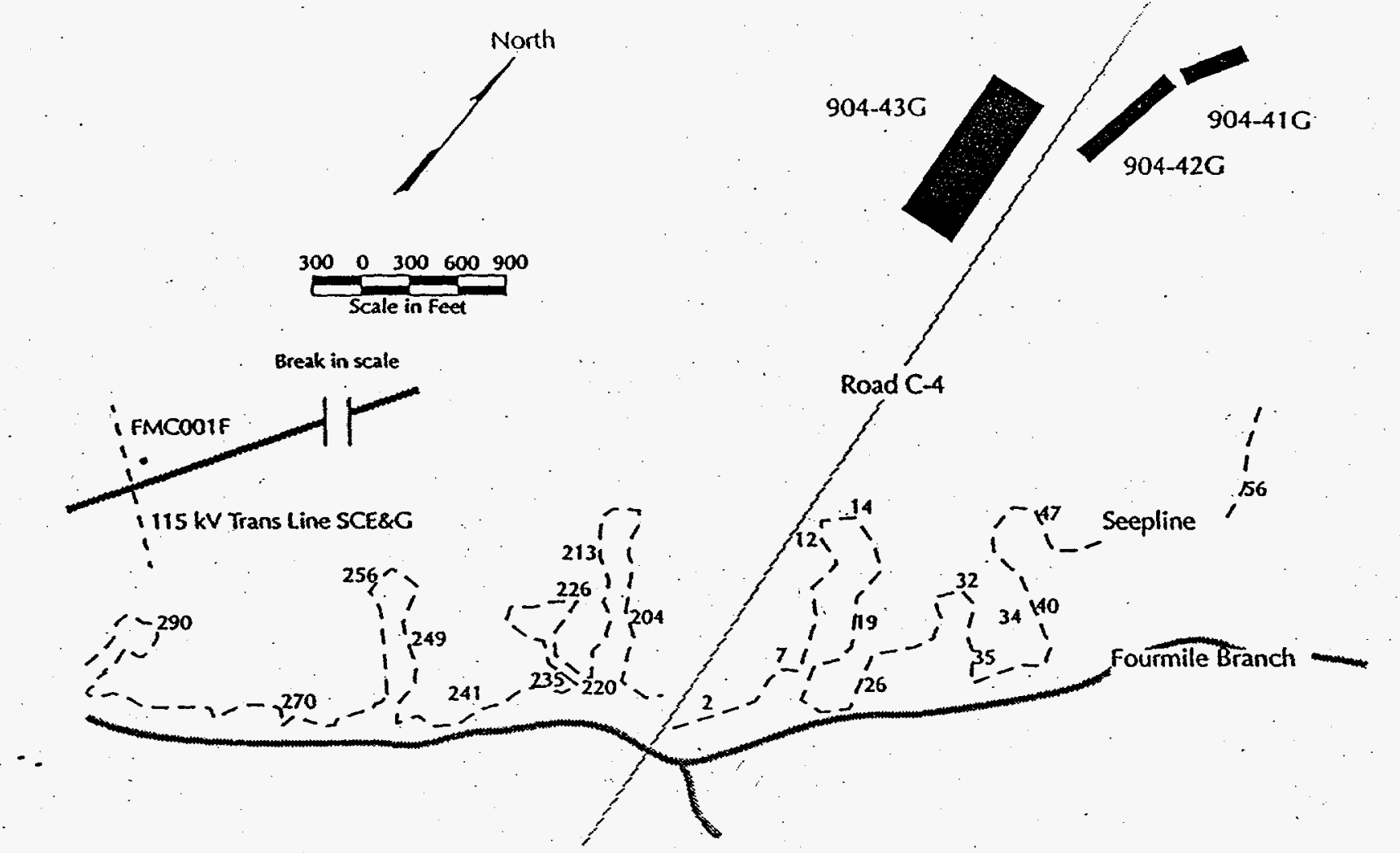

Figure 1. Location of F-Area Seepage Basins and Seepline Sampling Points.

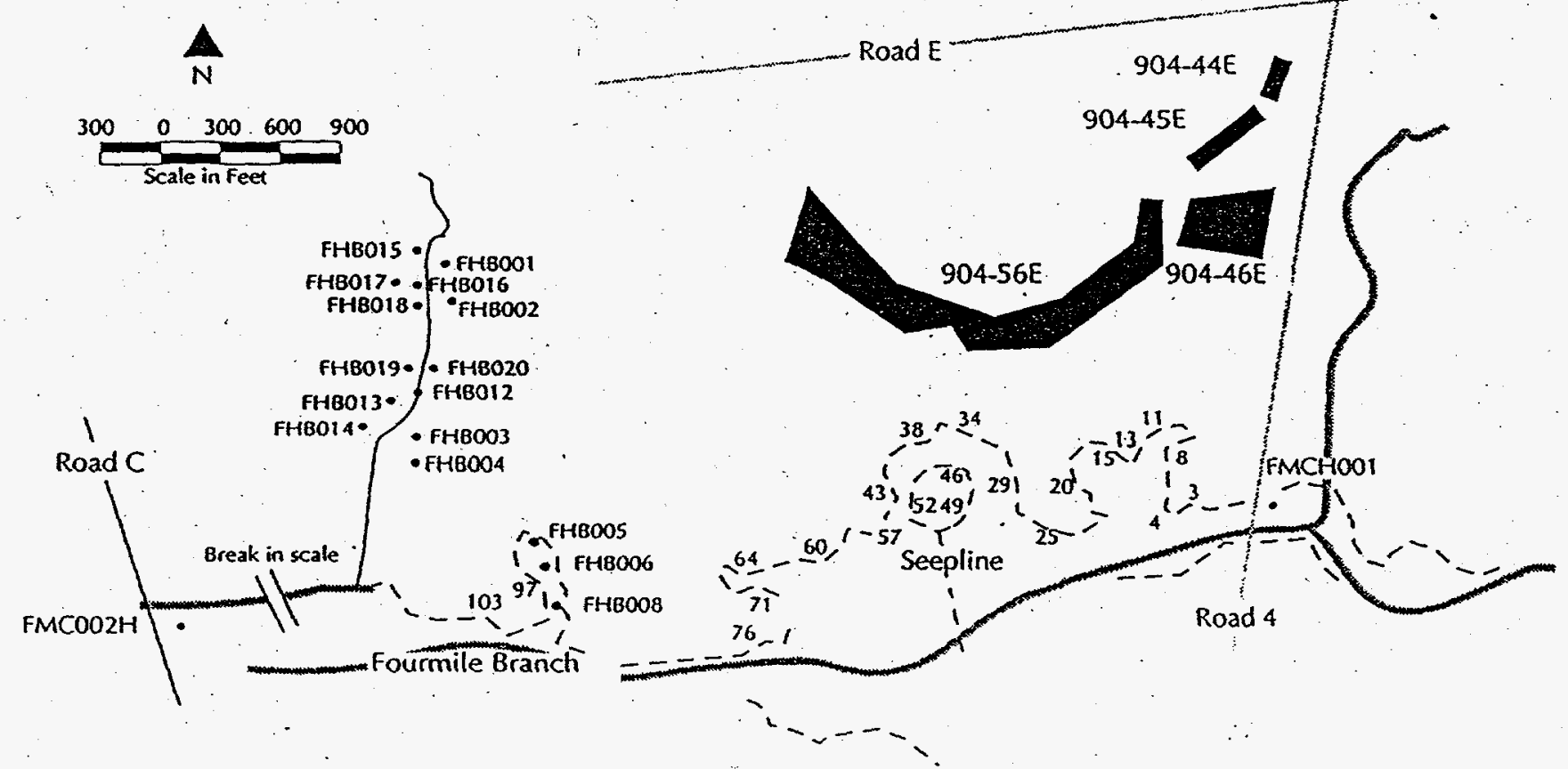

Figure 2. Location of H-Area Seepage Basins and Seepline Sampling Points and FHB Sampling Points. 


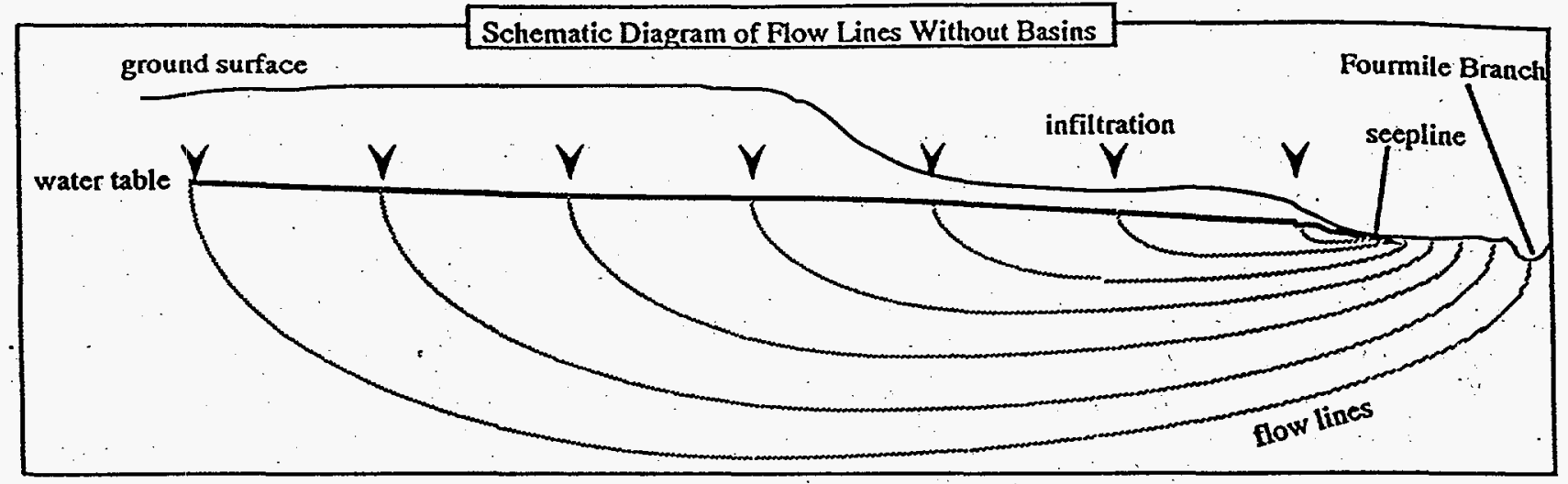

Figure 3. Schematic Diagram of Flow Lines in the Shallow Groundwater at the F-and H-Area without Seepage Basins

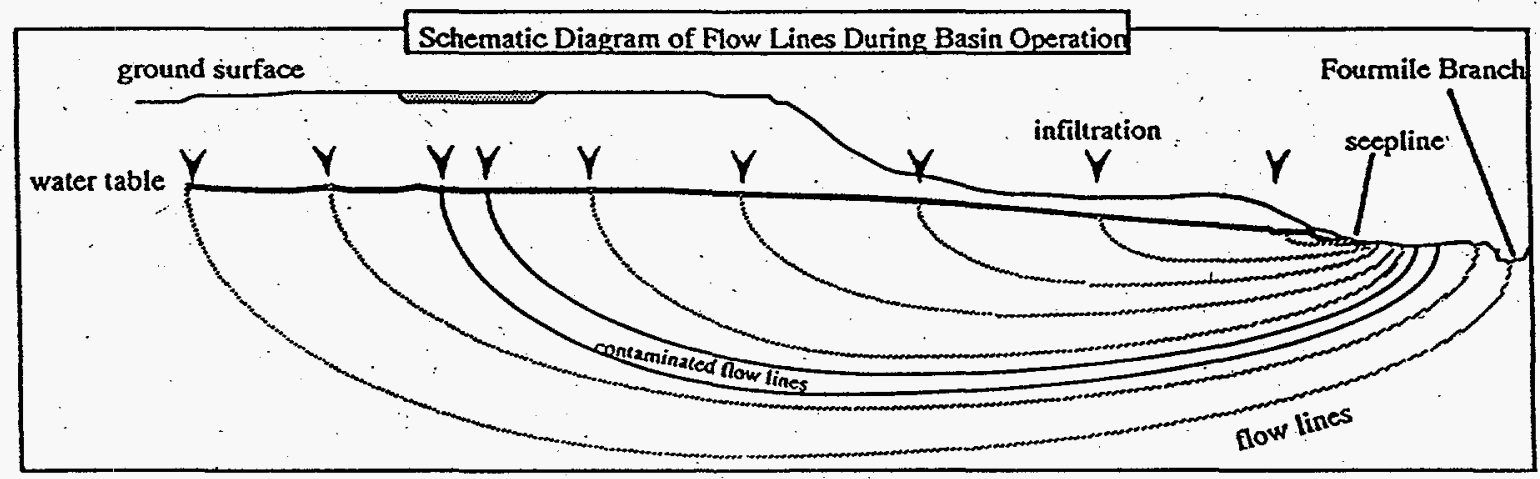

Figure 4. Schematic Diagram of Flow Lines in the Shallow Groundwater at the F-and H-Area Seepline during Basin Operation 


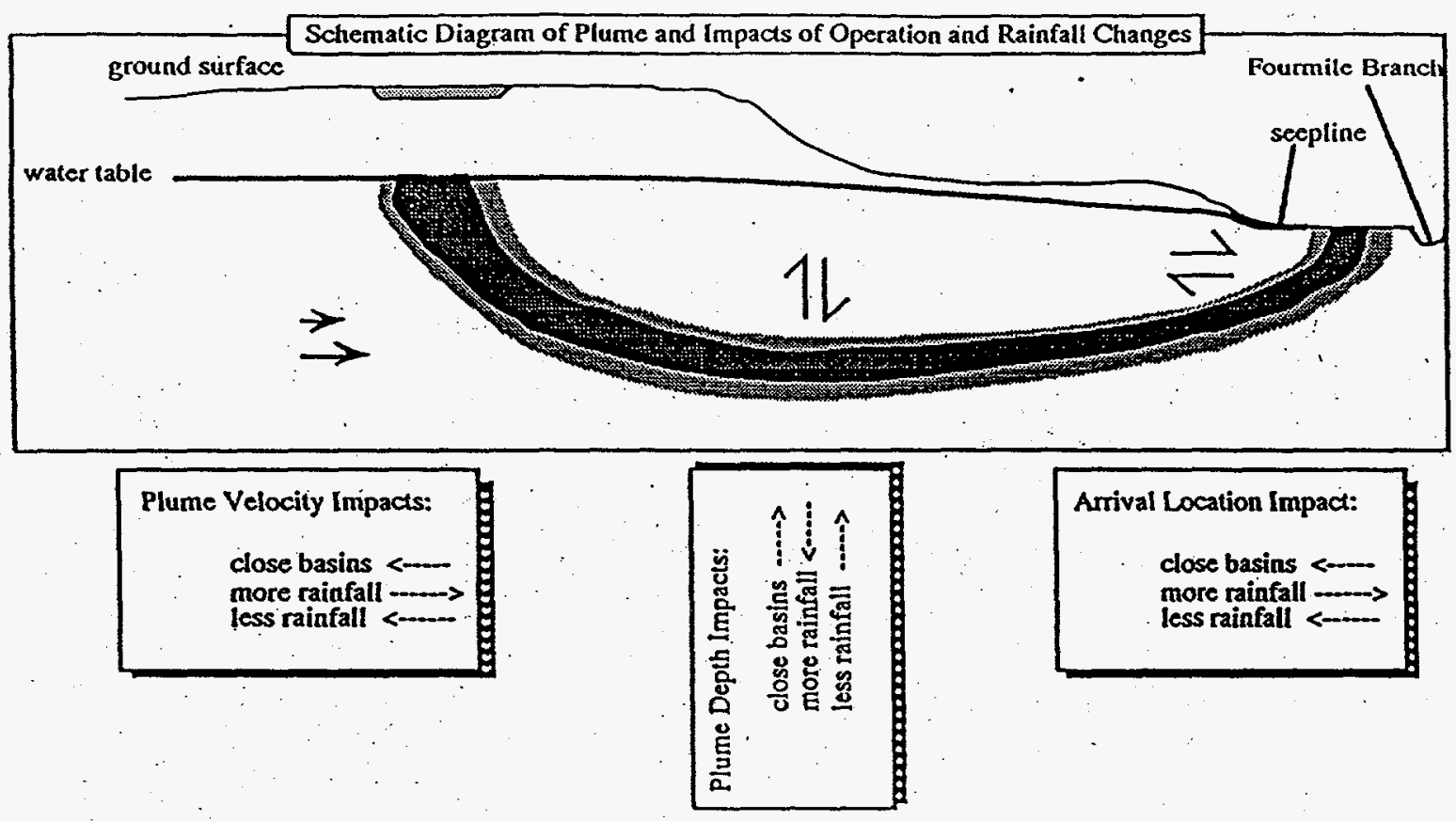

Figure 5. Schematic Diagram of the Tritium Plume Migrating from F- and H-Area Seepage Basins

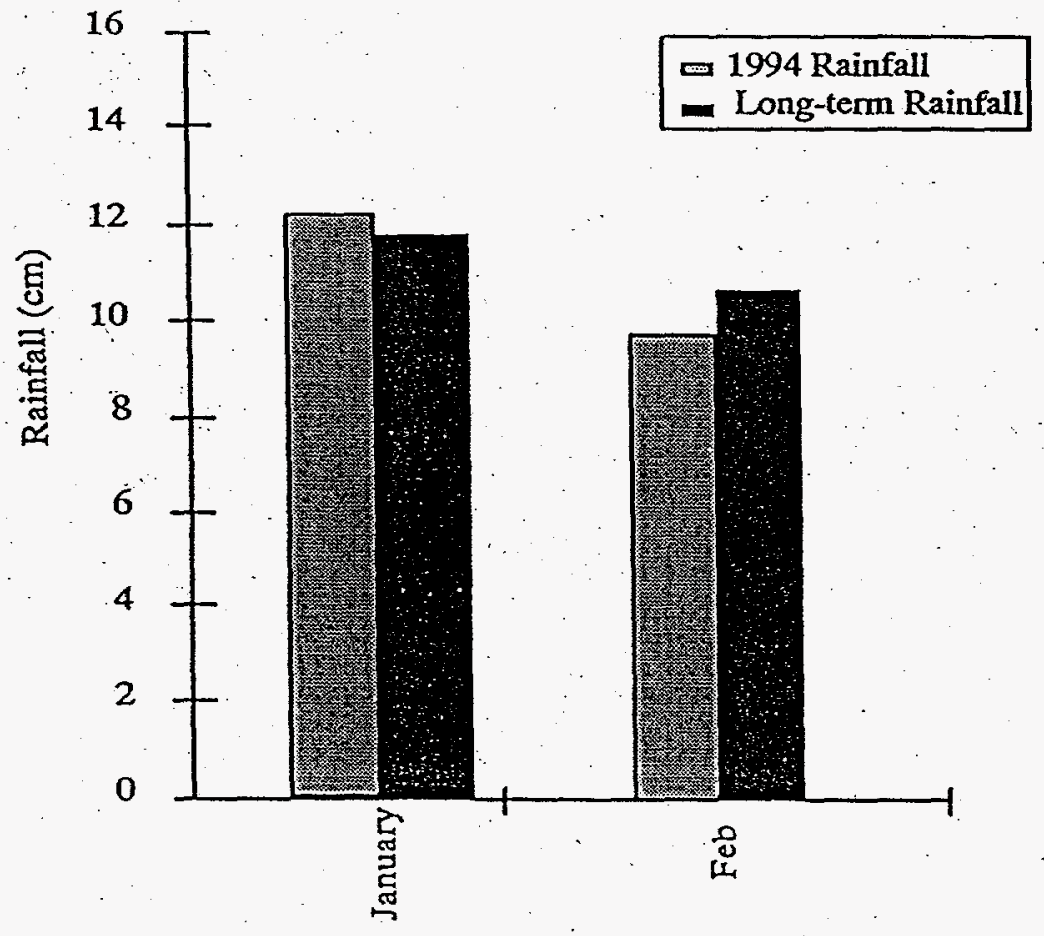

Figure 6. Comparison of 1994 Rainfall Totals (January-February) to the Long-Term Average (1960-1991) for F-Area Weather Station 


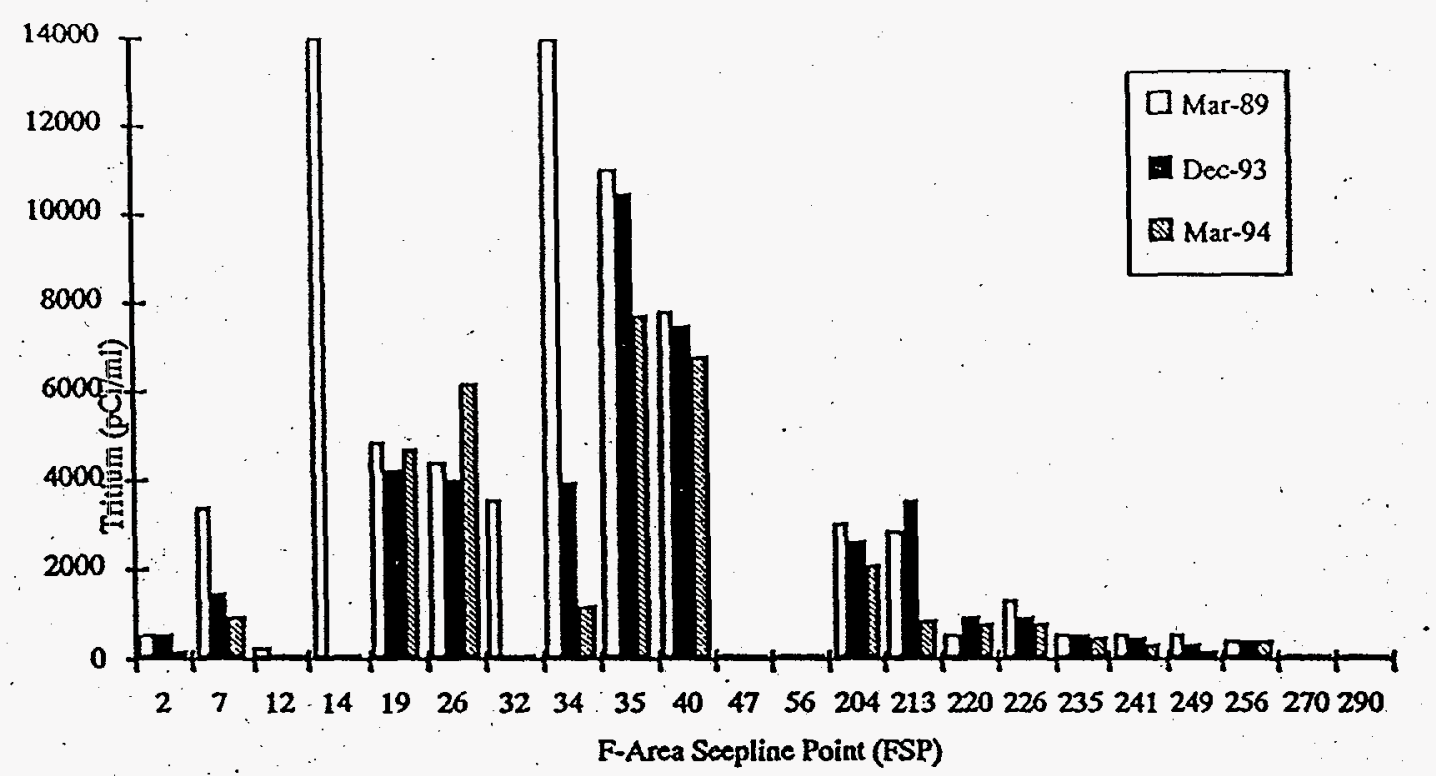

Figure 7. Comparison of March 1989, December 1993, and March 1994, Tritium Concentrations for Selected F-Area Seepline Locations

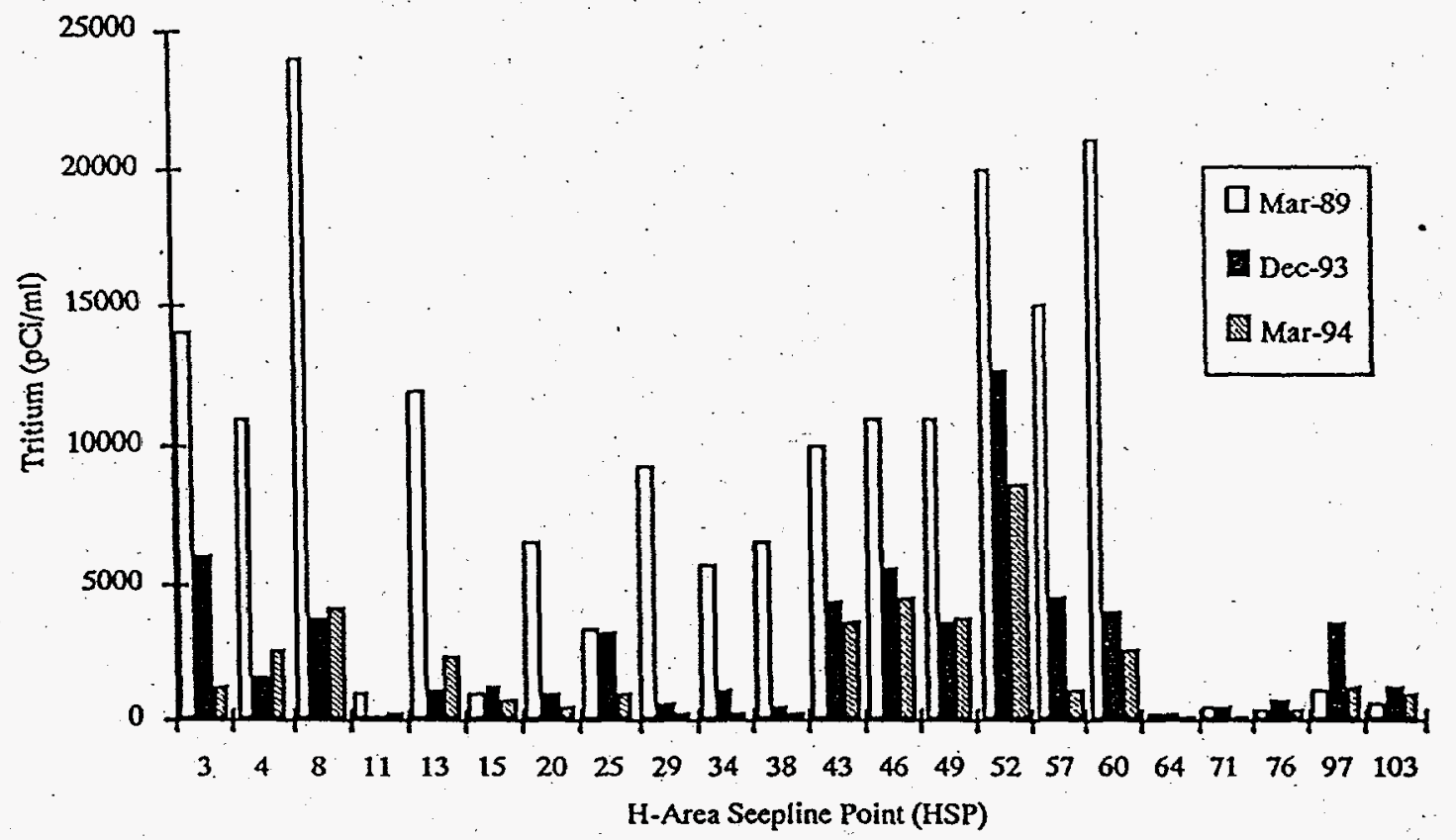

Figure 8. Comparison of March 1989, December 1993, and March 1994, Tritium Measurements for Selected H-Area Seepline Locations 


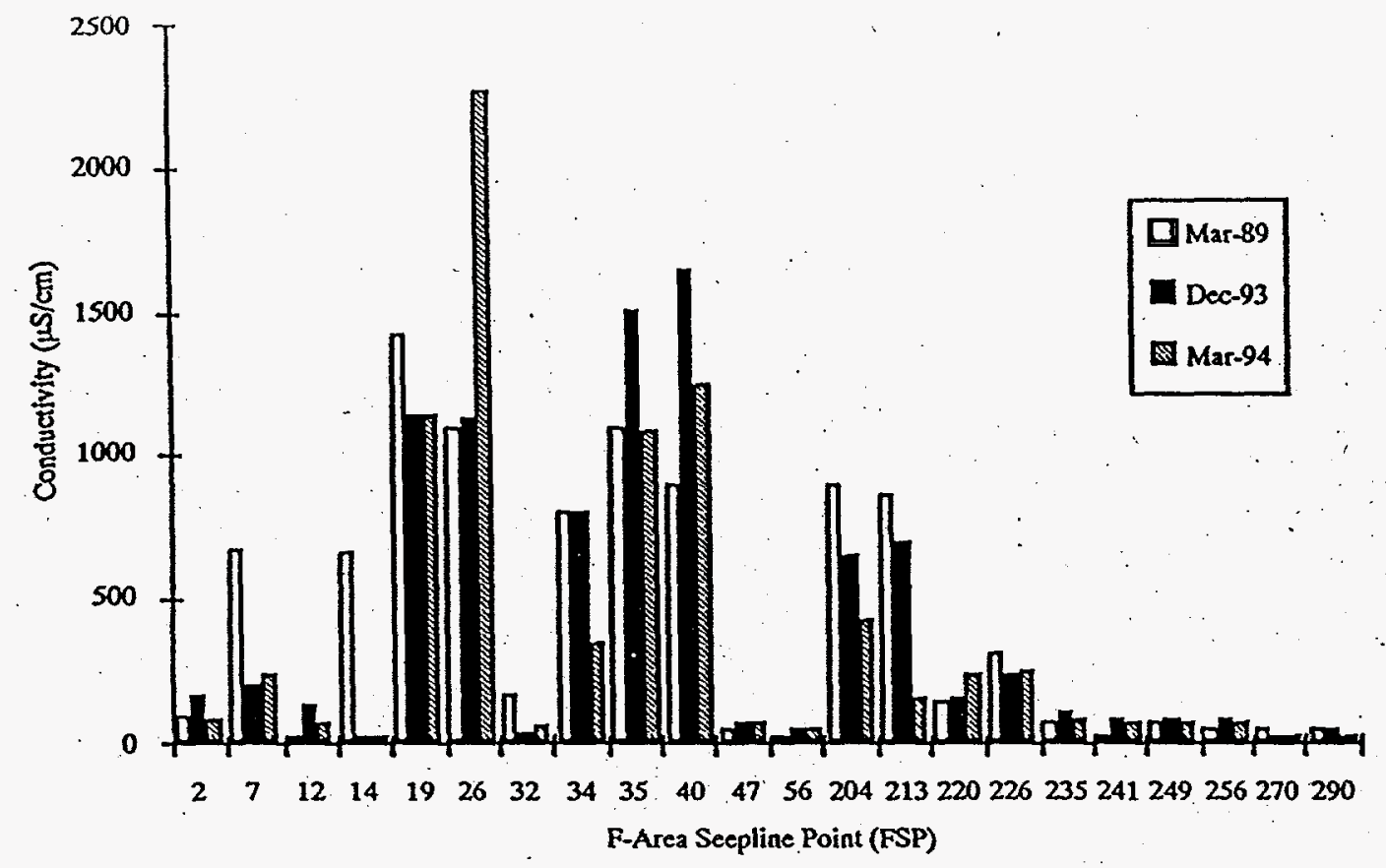

Figure 9. Comparison of March 1989, December 1993, and March 1994, Conductivity Measurements for Selected F-Area Seepline Locations

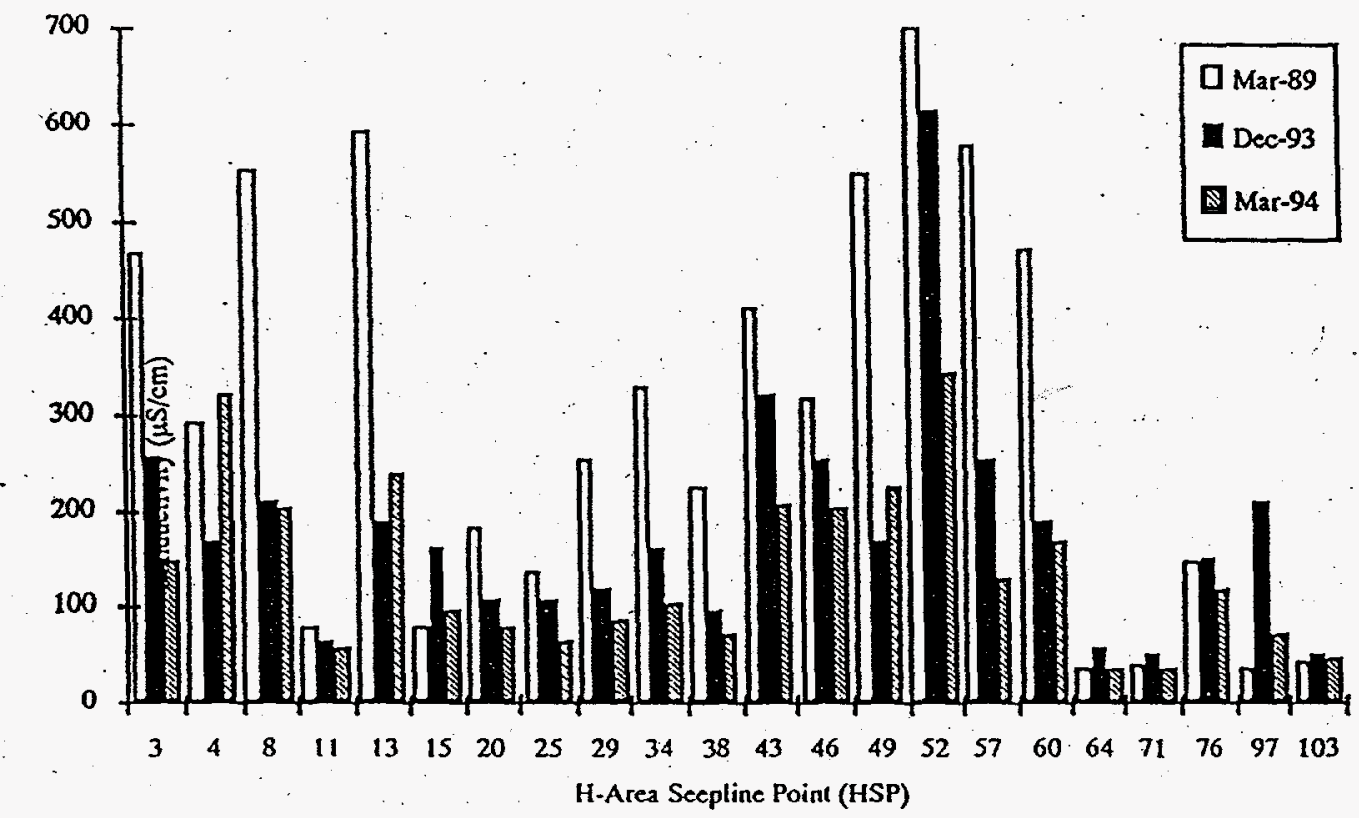

Figure 10. Comparison of March 1989, December 1993, and March 1994, Conductivity Measurements for Selected H-Area Seepline Locations 


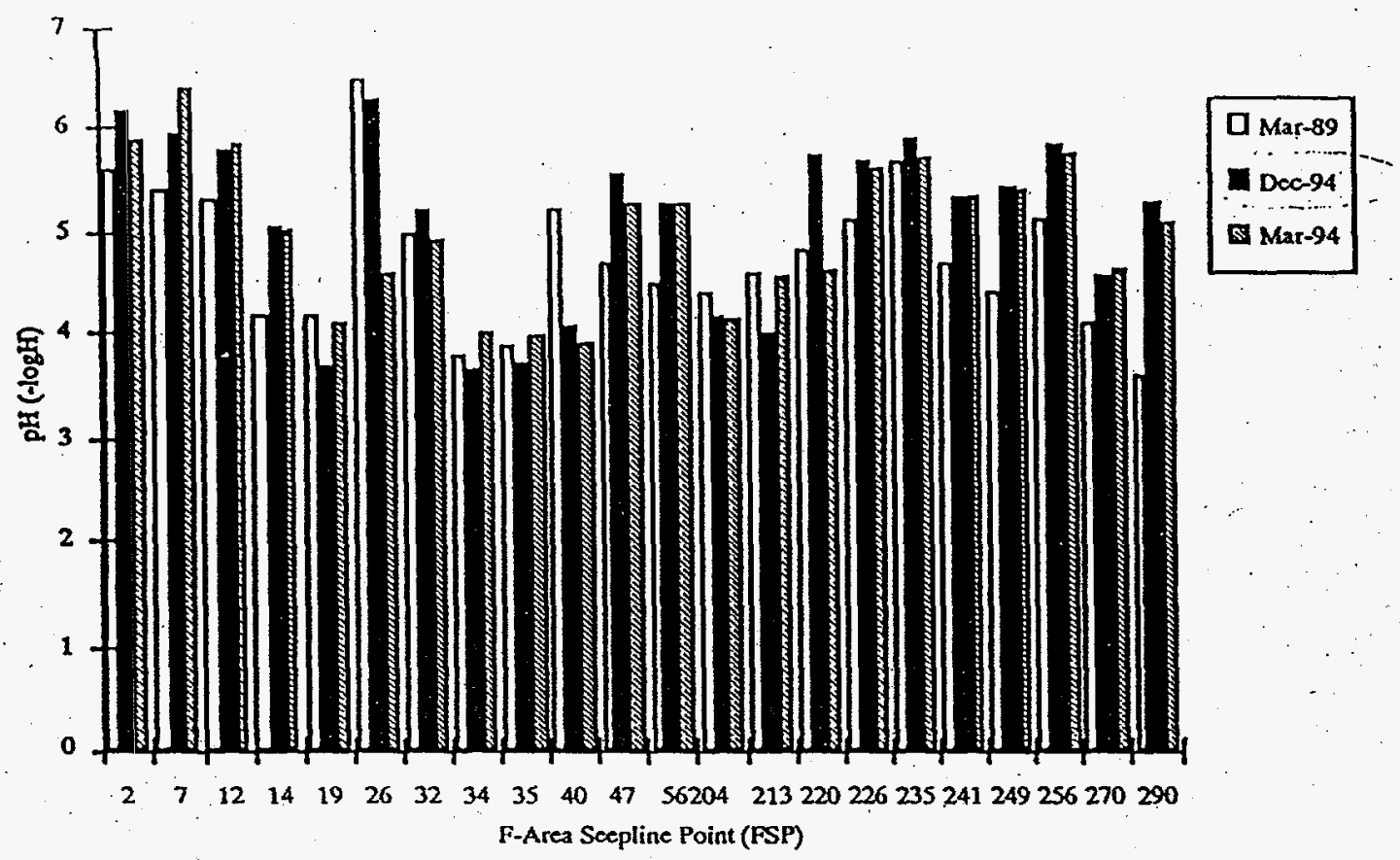

Figure 11. Comparison of March 1989, December 1993, and March 1994, pH Measurements for Selected F-Area Seepline Locations

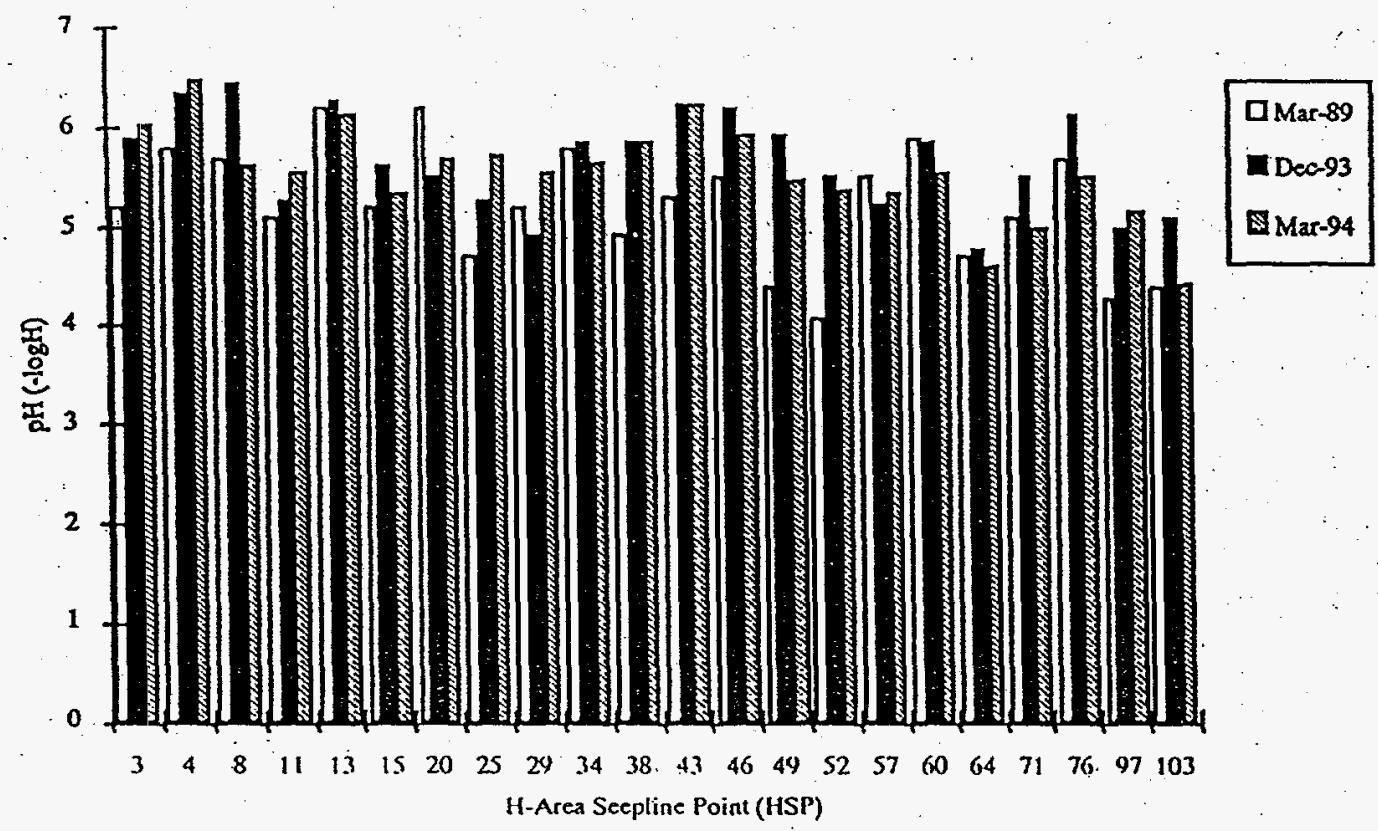

Figure 12. Comparison of March 1989, December 1993, and March 1994, pH Measurements for Selected H-Arca Scepline Locations 


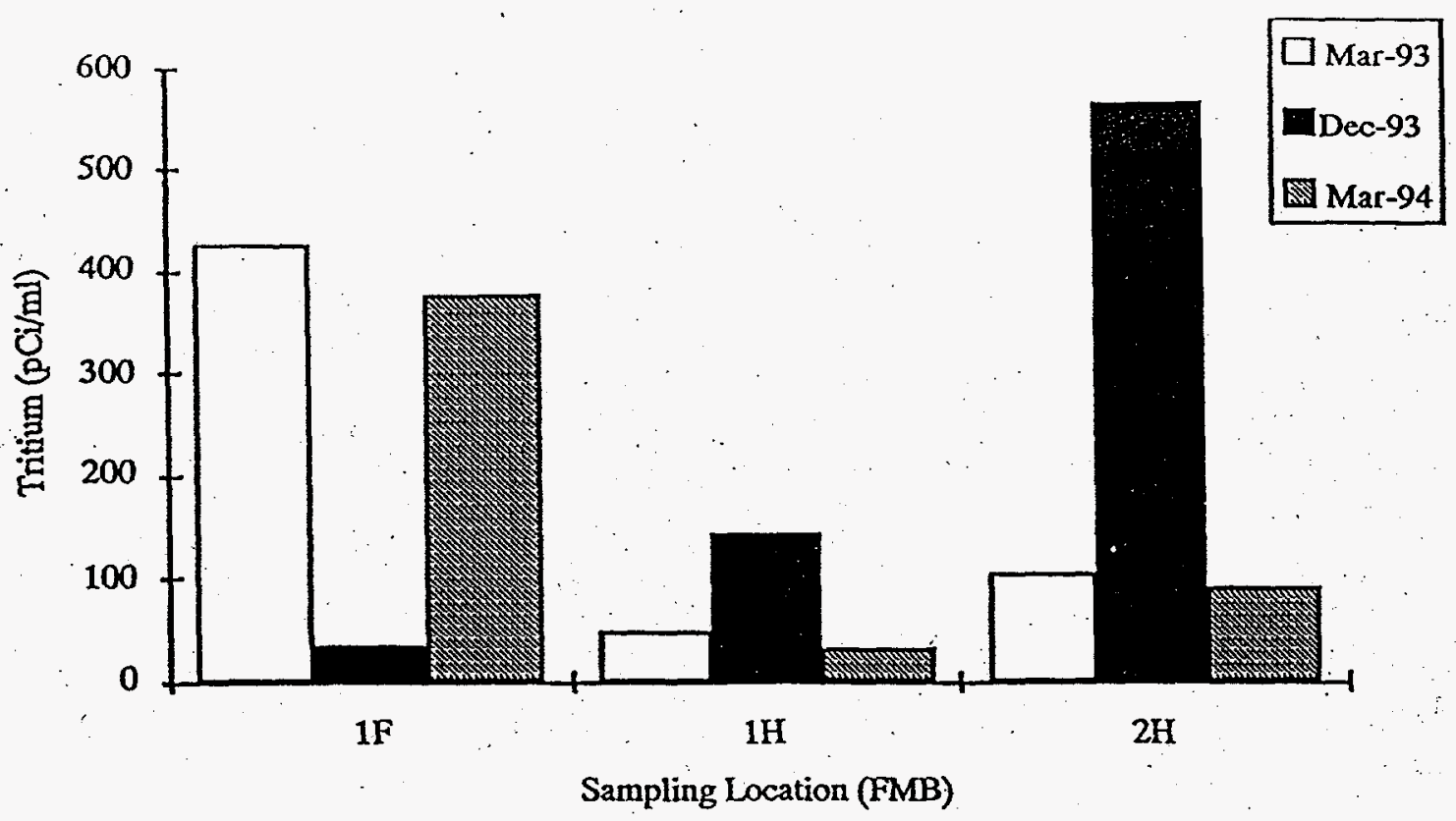

Figure 13. March and December 1993 and March 1994 Tritium Measurements for Selected Fourmile Branch Locations

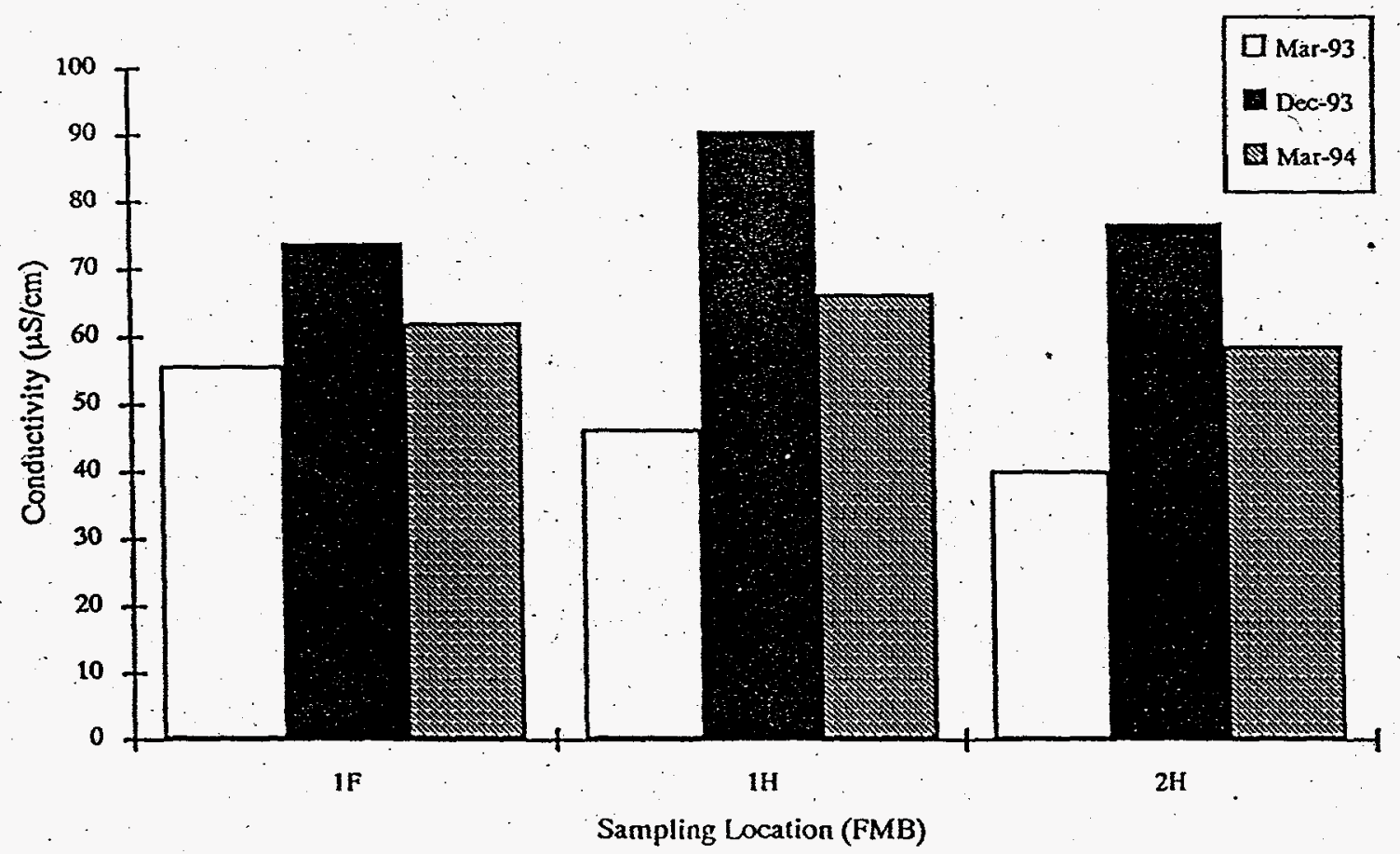

Figure 14. March, September, and December 1993 and March 1994 Conductivity Measurements for Selected Fourmile Branch Locations 


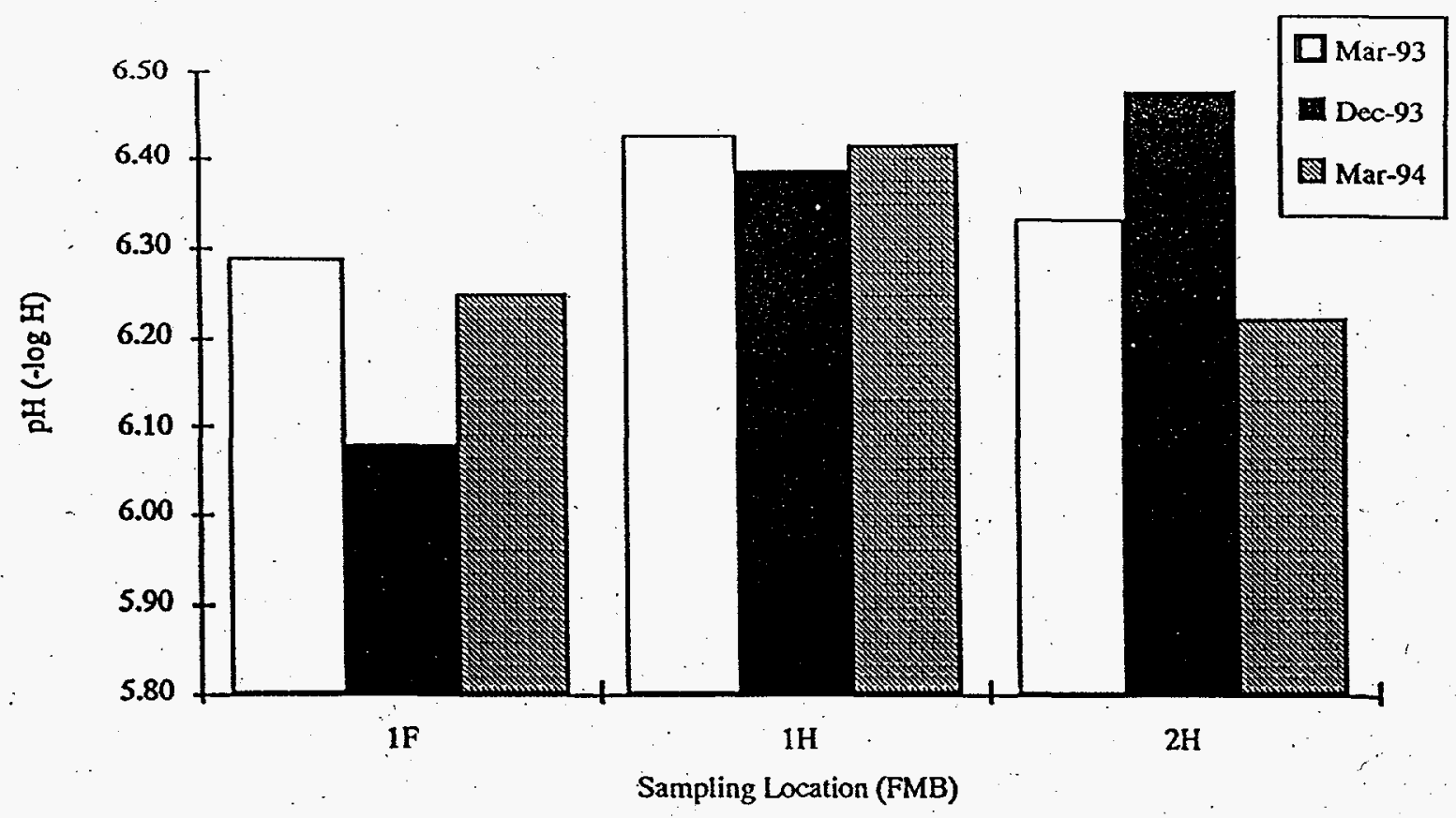

Figure 15. March and December 1993 and March $1994 \mathrm{pH}$ Measurements for Selected Fourmile Branch Locations

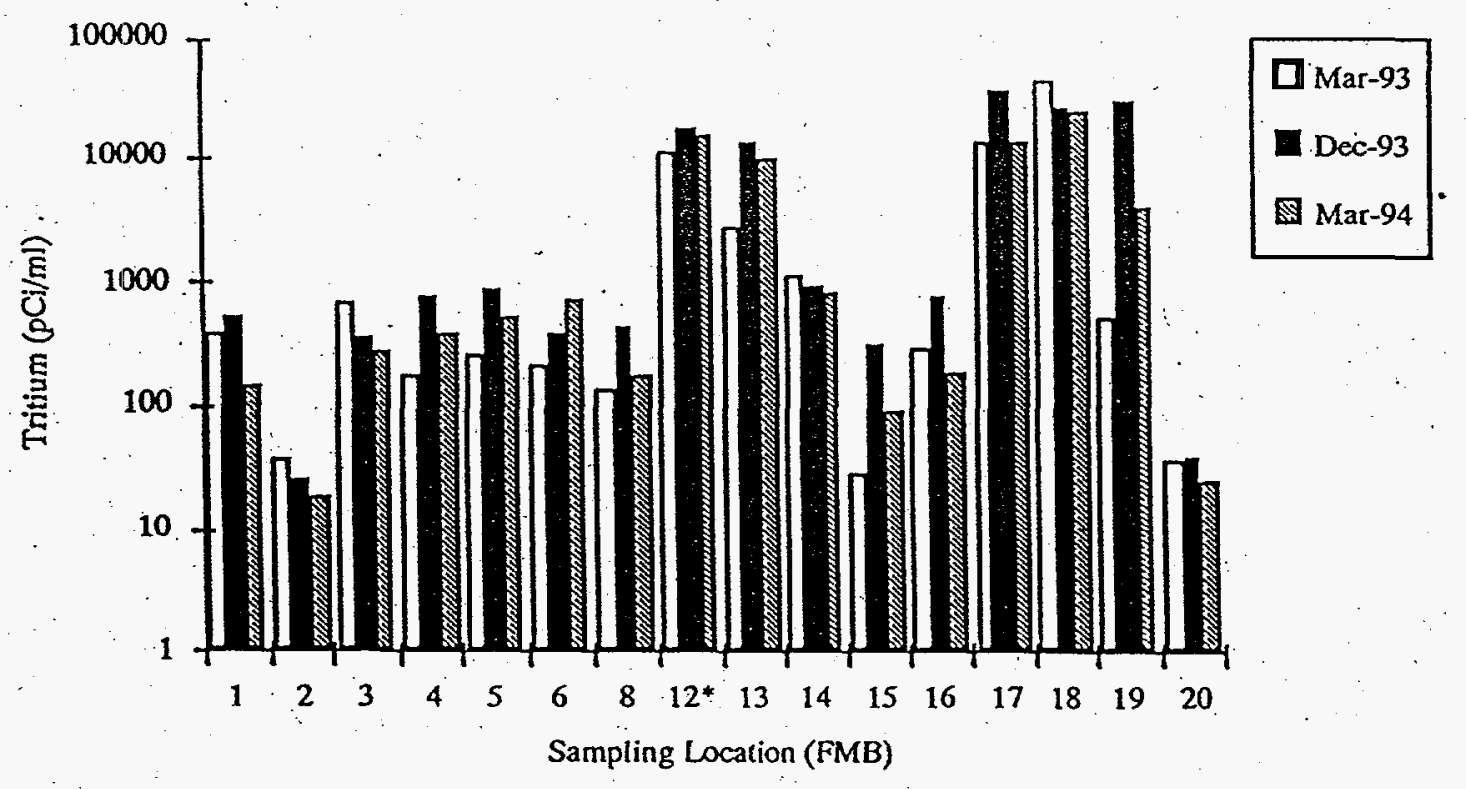

Figure 16. Comparison of March and December 1993 and March 1994 Tritium Concentrations for Selected Locations on the Seepline South of 643-E 


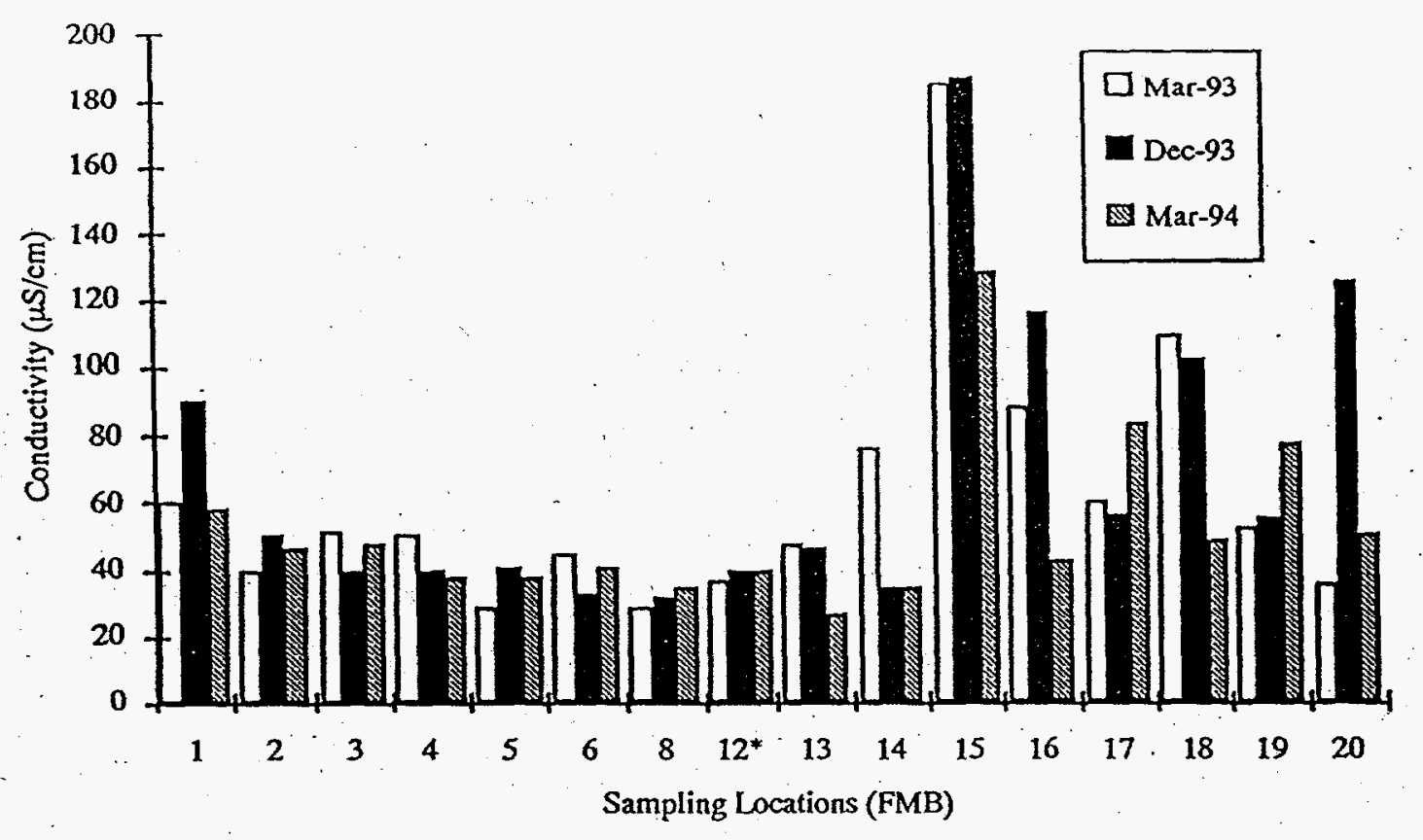

Figure 17. Comparison of March and December 1993 and March 1994 Conductivity Measurements for Selected Locations on the Seepline South of 643-E

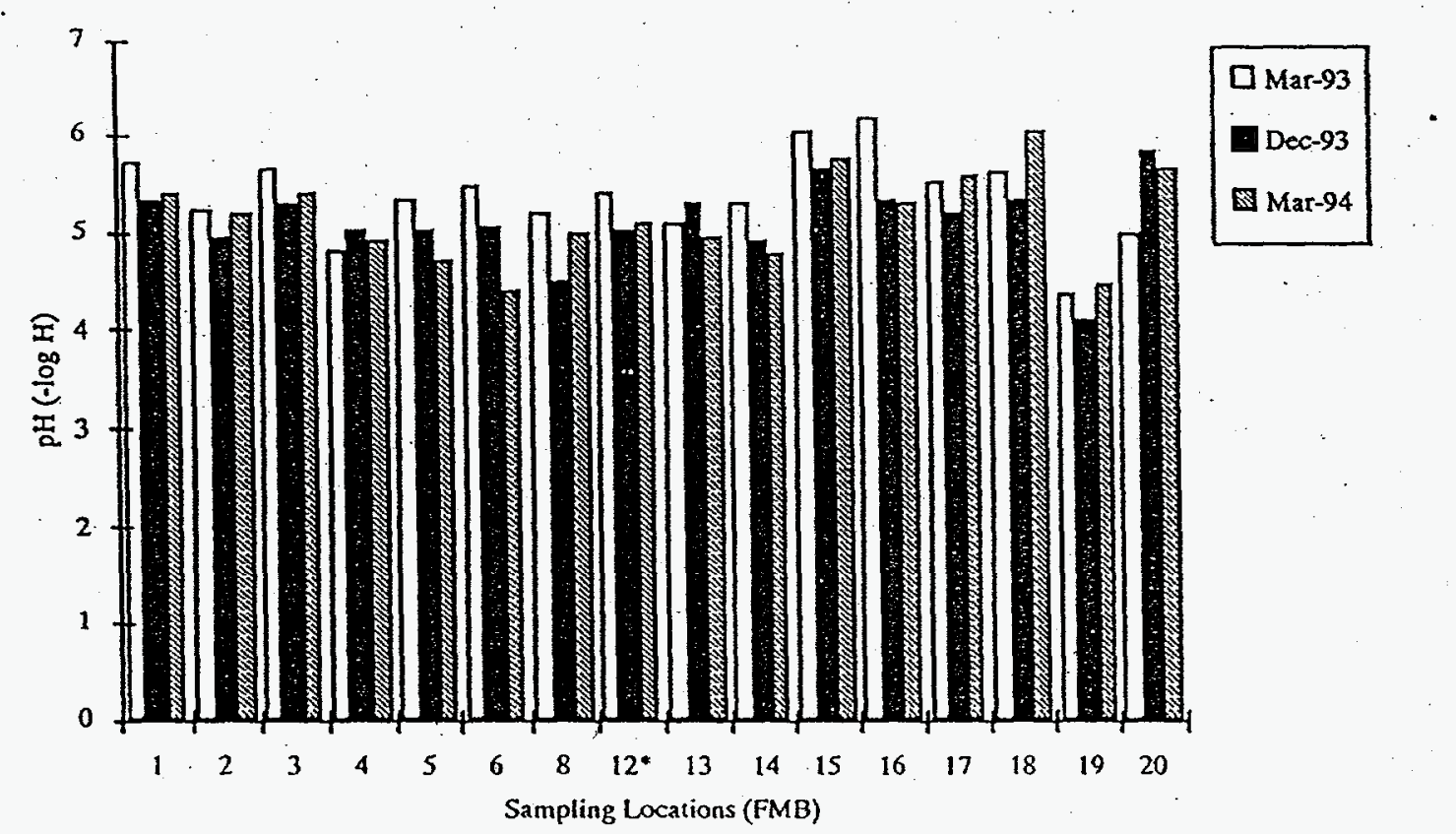

Figure 18. Comparison of March and December 1993 and March $1994 \mathrm{pH}$ Measurements for Selected Locations on the Scepline South of 643-E 
Table 1. Comparison of 1993 and 1994 Monthly Rainfall to the Long-Term Average Rainfall (1960-1991) from the F-Area Weather Station

\begin{tabular}{lcc} 
Month & $\begin{array}{c}\text { Rainfall (cm) } \\
(\mathbf{9 3 / 9 4 )}\end{array}$ & $\begin{array}{c}\text { Long-Term } \\
\text { Rainfall (cm) }\end{array}$ \\
\hline March 1993 & 21.5 & 13.3 \\
April 1993 & 3.5 & 8.6 \\
May 1993 & 4 & 10.7 \\
June 1993 & 15.3 & 10.9 \\
July 1993 & 7.3 & 12.9 \\
August 1993 & 8.8 & 14.3 \\
September 1993 & 16.7 & 9.5 \\
October 1993 & 1.6 & 5.7 \\
November 1993 & 5.8 & 6.6 \\
December 1993 & 4.5 & 9.5 \\
January 1994 & 12.2 & 11.8 \\
February 1994 & 8.9 & 10.8
\end{tabular}


Table 2. Comparison of F-Area Seepline Measurements of Tritium, Conductivity, and $\mathrm{pH}$ for March 1989, December 1993, and March 1994

\begin{tabular}{|c|c|c|c|c|c|c|c|c|c|}
\hline \multirow[b]{2}{*}{ Location } & \multicolumn{3}{|c|}{ Tritium (pCi/ml) } & \multicolumn{3}{|c|}{ Conductivity $(\mu \mathrm{S} / \mathrm{cm})$} & \multicolumn{3}{|c|}{ pH(- $\log H)$} \\
\hline & $\begin{array}{c}\text { March } \\
1989 \\
\end{array}$ & $\begin{array}{c}\text { December } \\
1993 \\
\end{array}$ & $\begin{array}{c}\text { March } \\
1994\end{array}$ & $\begin{array}{c}\text { March } \\
1989 \\
\end{array}$ & $\begin{array}{c}\text { December } \\
1993 \\
\end{array}$ & $\begin{array}{c}\text { March } \\
1994 \\
\end{array}$ & $\begin{array}{c}\text { March } \\
1989 \\
\end{array}$ & $\begin{array}{c}\text { December } \\
1993 \\
\end{array}$ & $\begin{array}{c}\text { March } \\
1994 \\
\end{array}$ \\
\hline 2 & 520 & 579 & 128 & 94 & 169 & 87 & 5.6 & 6.20 & 5.89 \\
\hline 7 & 3400 & 1460 & 946 & 681 & 199 & 233 & 5.4 & 5.94 & 6.40 \\
\hline 12 & 260 & 92 & 28 & 30 & 133 & 70 & 5.3 & 5.79 & 5.86 \\
\hline 14 & 14000 & 15 & 16. & 666 & 27 & 27 & 4.2 & 5.05 & 5.02 \\
\hline 19 & 4900 & 4237 & 4730 & 1424 & 1138 & 1143 & 4.2 & 3.70 & 4.10 \\
\hline 26 & 4400 & 4019 & 6150 & 1095 & 1135 & 2264 & 6.5 & 6.32 & 4.60 \\
\hline 32 & 3600 & 53 & 23 & 174 & 40 & 63 & 5.0 & 5.20 & 4.94 \\
\hline 34 & 14000 & 3884 & 1110 & 810 & 803 & 346 & 3.8 & 3.68 & 4.03 \\
\hline 35 & 11000 & 10436 & 7730 & 1100 & 1511 & 1085 & 3.9 & 3.73 & 3.98 \\
\hline 40 & 7800 & 7434 & 6790 & 900 & 1650 & 1259 & 5.2 & 4.06 & 3.93 \\
\hline 47 & 100 & 23 & 14 & 52 & 77 & 83 & 4.7 & 5.57 & 5.28 \\
\hline 56 & 19 & 13 & 11 & 34 & 54 & 51 & 4.5 & 5.28 & 5.27 \\
\hline 204 & 3000 & 2623 & 2100 & 895 & 650 & 428 & 4.4 & 4.20 & 4.15 \\
\hline 213 & 2800 & 3580 & 848 & 860 & 694 & 164 & 4.6 & 4.00 & 4.57 \\
\hline 220 & 560 & 989 & 742 & 147 & 162 & 232 & 4.8 & 5.75 & 4.63. \\
\hline 226 & 1300 & 967 & 823 & 306 & 234 & 255 & 5.1 & 5.70 & 5.61 \\
\hline 235 & 580 & 529 & 491 & 84 & 107 & 92 & 5.7 & 5.93 & 5.74 \\
\hline 241 & 560 & 496 & 286 & 36 & 92 & 78 & 4.7 & 5.35 & 5.33 \\
\hline 249 & 580 & 297 & 147 & 84 & $87^{\circ}$ & 70 & 4.4 & 5.43 & 5.41 \\
\hline 256 & 400 & 397 & 363 & 56 & 94 & 77 & 5.1 & 5.87 & 5.76 \\
\hline 270 & 40 & 63 & 37 & 50 & 30 & 29 & 4.1 & 4.56 & 4.62 \\
\hline 290 & 35 & 48 & 26 & 49 & 47 & 31 & 3.6 & 5.29 & 5.08 \\
\hline
\end{tabular}


Table 3. Comparison of H-Area Secpline Measurements for Tritium, Conductivity, and $\mathrm{pH}$ for March 1989, December 1993, and March 1994

\begin{tabular}{|c|c|c|c|c|c|c|c|c|c|}
\hline \multirow[b]{2}{*}{ Location } & \multicolumn{3}{|c|}{ Tritium $(\mathrm{pCi} / \mathrm{ml})$} & \multicolumn{3}{|c|}{ Conductivity $(\mu \mathrm{S} / \mathrm{cm})$} & \multicolumn{3}{|c|}{$\mathbf{p H}(-\log \mathbf{H})$} \\
\hline & $\begin{array}{c}\text { March } \\
1989 \\
\end{array}$ & $\begin{array}{c}\text { December } \\
1993\end{array}$ & $\begin{array}{l}\text { March } \\
1994 \\
\end{array}$ & $\begin{array}{c}\text { March } \\
1989 \\
\end{array}$ & $\begin{array}{c}\text { December } \\
1993\end{array}$ & $\begin{array}{c}\text { March } \\
1994 \\
\end{array}$ & $\begin{array}{c}\text { March } \\
1989 \\
\end{array}$ & $\begin{array}{c}\text { December } \\
1993 \\
\end{array}$ & $\begin{array}{c}\text { March } \\
1994 \\
\end{array}$ \\
\hline 3 & 14000 & 6050 & 1140 & 468 & 259 & 148 & 5.2 & 5.90 & 6.03 \\
\hline 4 & 11000 & 1570 & 2650 & 292 & 166 & 321 & 5.8 & 6.35 & 6.48 \\
\hline 8 & 24000 & 3730 & 4050 & 556 & 213 & 205 & 5.7 & 6.43 & 5.61 \\
\hline 11 & 960 & 116 & 237 & 80 & 67 & 60 & 5.1 & 5.26 & 5.55 \\
\hline 13 & 12000 & 1055 & 2260 & 592 & 191. & 238 & 6.2 & 6.29 & 6.13 \\
\hline 15 & 1000 & 1250 & 772 & 82 & 160 & 99 & 5.2 & 5.60 & 5.33 \\
\hline 20 & 6500 & 971 & 423 & 183 & 109 & 78 & 6.2 & 5.52 & 5.70 \\
\hline 25 & 3300 & 3119 & 963 & 135 & 107 & 64 & 4.7 & 5.26 & $5.72^{\circ}$ \\
\hline 29 & 9200. & 597 & 284 & 257 & 119 & 86 & 5.2 & 4.92 & 5.57 \\
\hline 34 & 5600 & 1058 & 164 & 331 & 163 & 104 & 5.8 & 5.86 & 5.64 \\
\hline 38 & 6500 & 465 & 303 & 227 & 98 & 74 & 4.9 & 5.87 & 5.86 \\
\hline 43 & 10000 & 4213 & 3530 & 413 & 323 & 209 & 5.3 & 6.24 & 6.25 \\
\hline 46 & 11000 & 5459 & 4460 & 318 & 257 & 204 & 5.5 & 6.22 & 5.92 \\
\hline 49 & 11000 & 3536 & 3680 & 551. & 170 & 226 & 4.4 & 5.94 & 5.47 \\
\hline 52 & 20000 & 12688 & 8650 & 699 & 612 & 344 & 4.1 & 5.50 & 5.39 \\
\hline 57 & 15000 & .4434 & 1070 & 581 & 256 & 129 & 5.5 & 5.24 & 5.33 \\
\hline 60 & $21000^{\circ}$ & 3901 & 2660 & 473 & 188 & 169 & 5.9 & 5.86 & 5.54 \\
\hline 64 & 320 & 179 & 42 & 38 & 56 & 35 & 4.7 & 4.80 & 4.63 \\
\hline 71 & 450 & 479 & . 106 & 40 & 52 & 35 & 5.1 & 5.50 & 4.99 . \\
\hline 76 & 400 & 768 & 349 & 146 & 150 & 120 & 5.7 & 6.14 & 5.52 \\
\hline 97 & 1100 & 3617 & 1270 & 37. & 210 & 74 & 4.3 & 5.00 & 5.15 \\
\hline 103 & 510 & 1218 & 930 & 43 & 53 & 47 & 4.4 & 5.08 & 4.45 \\
\hline
\end{tabular}

Table 4. Comparison of Fourmile Branch Stream Measurements for Tritium, Conductivity, and pH

\begin{tabular}{|c|c|c|c|c|c|c|c|c|c|}
\hline \multirow[b]{2}{*}{ Location } & \multicolumn{3}{|c|}{ Tritium (pCi/ml) } & \multicolumn{3}{|c|}{ Conductivity $(\mu \mathrm{S} / \mathrm{cm})$} & \multicolumn{3}{|c|}{$\mathrm{pH}(-\log H)$} \\
\hline & $\begin{array}{c}\text { March } \\
1989 . \\
\end{array}$ & $\begin{array}{c}\text { December } \\
1993\end{array}$ & $\begin{array}{c}\text { March } \\
1994 \\
\end{array}$ & $\begin{array}{c}\text { March } \\
1989 \\
\end{array}$ & $\begin{array}{c}\text { December } \\
1993\end{array}$ & $\begin{array}{c}\text { March } \\
1994 \\
\end{array}$ & $\begin{array}{c}\text { March } \\
1989\end{array}$ & $\begin{array}{c}\text { December } \\
1993\end{array}$ & $\begin{array}{c}\text { March } \\
1994 \\
\end{array}$ \\
\hline $1 F$ & 425 & 567 & 375 & 56 & 77 & 62 & 6.3 & 6.5 & 6.3 \\
\hline $1 \mathrm{H}$ & 47 & 37 & 34 & 46 & 74 & 67 & 6.4 & 6.1 & 6.4 \\
\hline $2 \mathrm{H}$ & 104 & 145 & 91 & 40 & 91 & 58 & 6.3 & 6.4 & 6.2 \\
\hline
\end{tabular}


Table 5. Comparison of Seepline Below the 643-E Measurements for Tritium, Conductivity, and $\mathrm{pH}$ for the March 1993, December 1993, and March 1994 Sampling Events

\begin{tabular}{|c|c|c|c|c|c|c|c|c|c|}
\hline \multirow[b]{2}{*}{ Location } & \multicolumn{3}{|c|}{ Tritium (pCi/ml) } & \multicolumn{3}{|c|}{ Conductivity $(\mu \mathrm{S} / \mathrm{cm})$} & \multicolumn{3}{|c|}{ pH(- $\log H)$} \\
\hline & $\begin{array}{c}\text { March } \\
1993 \\
\end{array}$ & $\begin{array}{c}\text { December } \\
1993 \\
\end{array}$ & $\begin{array}{c}\text { March } \\
1994\end{array}$ & $\begin{array}{c}\text { March } \\
1993 \\
\end{array}$ & $\begin{array}{c}\text { December } \\
1993 \\
\end{array}$ & $\begin{array}{c}\text { March } \\
1994\end{array}$ & $\begin{array}{c}\text { March } \\
1993 \\
\end{array}$ & $\begin{array}{c}\text { December } \\
1993 \\
\end{array}$ & $\begin{array}{c}\text { March } \\
1994 \\
\end{array}$ \\
\hline 1 & 387 & 553 & 143 & 60 & 91 & 58 & 5.8 & 5.35 & 5.44 \\
\hline 2 & 37 & 25 & 19 & 40 & 51 & 46 & 5.2 & 4.97 & 5.21 \\
\hline 3 & 682 & 370 & 293 & 52 & 40 & 47 & 5.7 & 5.32 & 5.44 \\
\hline 4 & 175 & 785 & 386 & 51 & 40 & 38 & 4.8 & 5.05 & 4.94 \\
\hline 5 & 263 & 907 & 551 & 29 & 40 & 38 & 5.4 & 5.03 & 4.70 \\
\hline 6 & 217 & 378. & 748 & 45 & 33 & 41 & 5.5 & 5.07 & 4.40 \\
\hline 8 & 134 & 419 & 172 & 29 & 32 & 34 & 5.2 & 4.52 & 5.00 \\
\hline${ }^{*} 12$ & 12000 & 18738 & 16100 & 37 & 40 & 40 & 5.4 & 5.03 & 5.09 \\
\hline 13 & 2860 & 13762 & 10200 & 47 & 46 & 27 & 5.1 & 5.32 & 4.97 \\
\hline 14 & 1150 & 939 & 812 & 77 & 34 & 35 & $5.3^{\circ}$ & 4.92 & 4.79 \\
\hline 15 & 29 & 315 & 95 & 185 & 187 & 128 & 6.0 & 5.68 & 5.77 \\
\hline 16 & 306 & 785 & 198 & 88 & 117 & 43 & 6.2 & 5.33 & 5.31 \\
\hline 17 & 14100 & 36383 & 14440 & 60 & 57 & 83 & 5.5 & 5.21 & 5.59 \\
\hline 18 & 44000 & 25966 & 24500 & 110 & 102 & 49 & 5.6 & 5.33 & 6.06 \\
\hline 19 & 546 & 30537 & 4190 & 52 & 55 & 77 & 4.4 & 4.13 & 4.46 \\
\hline 20 & 38 & 42 & 27 & 35 & 125 & 51 & 5.0 & 5.83 & 5.67 \\
\hline
\end{tabular}

*Stream Sample Location 